University of Cincinnati College of Law

University of Cincinnati College of Law Scholarship and

Publications

\title{
The Strange Career of the Three-Judge District Court: Federalism and Civil Rights, 1954-76
}

Michael E. Solimine

University of Cincinnati College of Law, michael.solimine@uc.edu

Follow this and additional works at: https://scholarship.law.uc.edu/fac_pubs

Part of the Civil Procedure Commons, and the Civil Rights and Discrimination Commons

\section{Recommended Citation}

Michael E. Solimine \& James L. Walker, Three-Judge District Court: Federalism and Civil Rights, 1954-76, 72 Case W. Res. L. Rev. 909 (2022).

This Article is brought to you for free and open access by the College of Law Faculty Scholarship at University of Cincinnati College of Law Scholarship and Publications. It has been accepted for inclusion in Faculty Articles and Other Publications by an authorized administrator of University of Cincinnati College of Law Scholarship and Publications. For more information, please contact ronald.jones@uc.edu. 


\title{
The Strange Career of the Three-Judge District Court: Federalism And Civil Rights, $1954-1976$
}

\author{
Michael E. Solimine \& James L. Walkeri†
}

\begin{abstract}
The three-judge district court has had a long and strange career in the history of the federal court system. Congress created the court in 1910 as a response to the canonical decision of Ex parte Young two years earlier, which permitted federal court suits against state officials to facilitate constitutional challenges to state laws. The three-judge court statute was a reaction by Progressive Era politicians to such perceived judicial overreach, and required any such challenges to be brought before a specially convened trial court of three judges, with a direct appeal to the Supreme Court available. First established as a presumed limit on judicial activism, decades later, plaintiffs in the Civil Rights Era came to see the court as advancing their agenda. Particularly in the South, some plaintiffs preferred to have their suits decided by three judges rather than the usual one, with a direct appeal available to a relatively friendly Warren Court. For that and other reasons, the total number of such cases in the district courts, and direct appeals to the Supreme Court, swelled in the 1960s and 1970s. But at the same time, the court came to be seen by many as administratively burdensome and unnecessary, and Congress in 1976 severely restricted the jurisdiction of the court, limiting it to hearing only reapportionment cases.
\end{abstract}

$\dagger \quad$ Donald P. Klekamp Professor of Law, University of Cincinnati College of Law. I dedicate this Article to the memory of my teacher, mentor, and good friend, Jim Walker, who passed away as we were researching and writing the Article. () 2021 by Michael E. Solimine.

$\dagger$ Professor of Political Science Emeritus, Wright State University (1942-2019).

We thank our excellent research assistants, students at the University of Cincinnati College of Law, for searching for and coding the three-judge district decisions that form the basis of our empirical study: Matt Allen, Silvia Arieria, Zach Cuni, Alexa Edwards, Betsy Emmert, Laura Gates, Danielle List, Allie Soisson and Eden Thompson. Thanks also to Josh Douglas, Jon Entin, Arthur Hellman, Connor Organ, Ed Purcell, Mila Sohoni, Stephen Wasby, Lael Weinberger, and to participants at a faculty workshop at the University of Cincinnati College of Law, for helpful comments on a prior draft. 
Analysis of the three-judge district court has so far largely relied on anecdotal evidence, and limited empirical studies, to examine whether some plaintiffs in the Civil Rights Era were correct to consider the court as friendly to their interests, as compared to a typical single district judge with the normal appeal process. This article breaks new ground and extends those studies by systematically reexamining these assumptions through a unique, nationwide database of 885 three-judge district court decisions, regarding constitutional challenges to state laws, handed down from 1954 (the start of the Warren Court) to 1976 (when Congress limited the Court's jurisdiction). The study provides greater and more complete information on the number, types and results of cases litigated in the court, as well as on the dispositions of appeals to the Supreme Court. Among our findings are that such court decisions were disproportionately in favor of plaintiffs, both in and outside the South, and that there was a high rate of appeal to the Supreme Court. We then consider how the decisions of the three-judge court, and its direct appeal mechanism, affected jurisprudential developments in several areas of civil rights litigation, including reapportionment and judicial abstention. We also address how these decisions impact the Judicial Capacity model, which posits that the sheer number of cases that come to the Court for review affects doctrinal developments. The study situates the three-judge district court in a richer historical context, and sheds light on the continued use of the court in more limited contexts to the present day.

\section{Contents}

I. Congress, Courts, Litigants, And the Three-Judge District

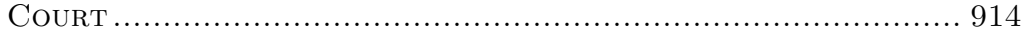

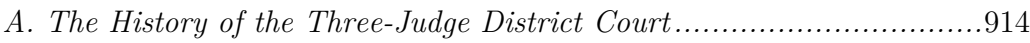

B. The Three-Judge District Court in the Civil Rights Era ...................925

II. Empirical Study of Three-Judge District Court Decisions in Civil Rights Cases, 1954-1976 ................................. 930

A. Data Collection, Case Coding, and Hypotheses............................... 930

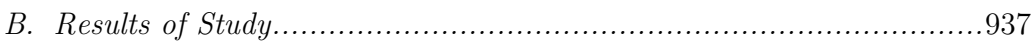

1. Overall Number and Types of Cases ..................................... 937

2. National and Regional Trends and Differences: Frequency and Results of Cases .............................................................. 940

3. Direct Appeals to the Supreme Court: Frequency and

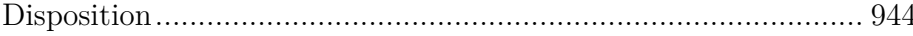

III. The Jurisprudential Impact of the Three-Judge District

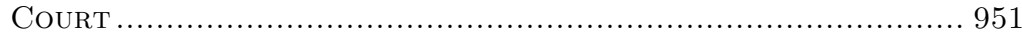

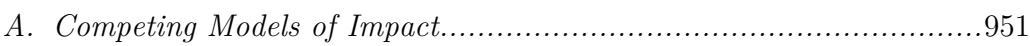

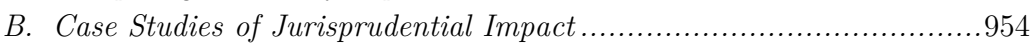

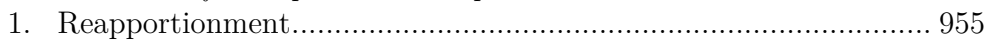

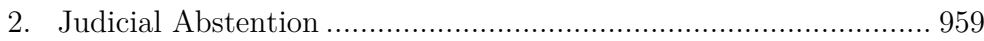

3. Judicial Capacity and Tiers of Scrutiny ................................... 967 
Case Western Reserve Law Review · Volume $72 \cdot$ Issue $4 \cdot 2022$

The Strange Career of the Three-Judge District Court

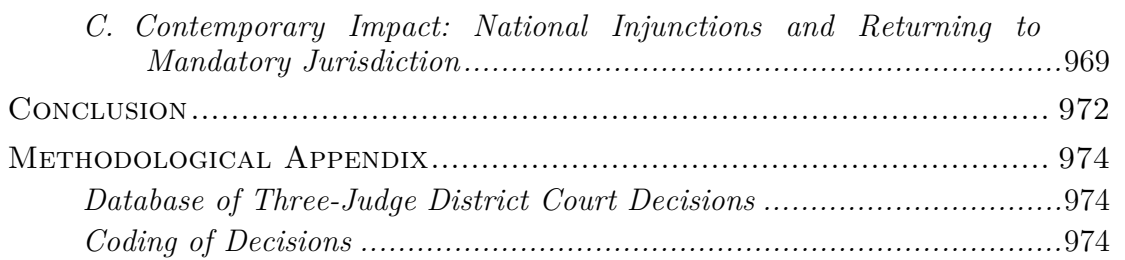

\section{INTRODUCTION}

Legal scholars have long examined federal courts' exercise of judicial review, which at its core is the judicial determination of whether a federal statute violates the U.S. Constitution. Such review of lawmaking by a coordinate branch of government raises both counter-majoritarian and separation-of-powers concerns. ${ }^{1}$ Similarly, legal scholarship has long examined how federal courts have judicially reviewed statutes passed by the States. That too raises counter-majoritarian concerns, but few, if any, issues from separation of powers. ${ }^{2}$ Instead, the latter is replaced by federalism concerns, the power of the federal government to supervise and possibly overturn the actions of state governments. ${ }^{3}$

This all covers familiar territory. What is possibly less familiar is that, over the course of American history, federal courts have taken different institutional paths in examining state statutes. Consider one recent high-profile example of federal courts reviewing and holding state statutes unconstitutional. In Obergefell v. Hodges ${ }^{4}$ a majority of the Supreme Court held that state same-sex marriage bans violated the Due Process Clause of the Fourteenth Amendment. ${ }^{5}$ While the bans of only four states were before the Court in consolidated cases, the Court effectively invalidated the similar bans of over thirty other states. ${ }^{6}$ The cases came to the Court through the unexceptional process of a civil rights action filed in a U.S. District Court before one judge, with review

1. Ittai Bar-Siman-Tov, The Puzzling Resistance to Judicial Review of the Legislative Process, 91 B.U. L. REv. 1915, 1926-1927 (2011).

2. Stefanie A. Lindquist \& Pamela C. Corley, National Policy Preferences and Judicial Review of State Statutes at the United States Supreme Court, 43 PUBlius 151, 153-54 (2013).

3. See id. at $152-53$.

4. 576 U.S. 644 (2015).

5. Id. at 675 .

6. Josh Blackman \& Howard M. Wasserman, The Process of Marriage Equality, 43 Hastings Const. L.Q. 243, 247 n.13 (2015). 
thereafter by a three-judge panel on a U.S. Court of Appeals, and by the Supreme Court through a discretionary writ of certiorari. ${ }^{7}$

But the path of such litigation would have been quite different had it been filed during a long period in the 20th century. Had it been litigated between 1910 and 1976, such suits would have been heard before specially convened three-judge district courts, consisting of the district judge before whom the case was originally filed, and two other judges appointed by the Chief Judge of the circuit, typically another district judge and a circuit judge. ${ }^{8}$ Any review of the decision of that three-judge panel would be by direct appeal to the Supreme Court, ${ }^{9}$ which at least ostensibly would be required to decide that appeal on its merits. A high-profile example of its use to invalidate many state laws, as a counterpoint to Obergefell, is the Court's 1973 decision on state abortion laws, Roe v. Wade. ${ }^{10}$

This article focuses on that less familiar story. Part I begins by describing the long and strange ${ }^{11}$ career of the three-judge district court. Congress created the court in 1910 as a response to the thencontroversial, now-iconic Supreme court decision of Ex parte Young. ${ }^{12}$ That decision permitted federal court suits against state officials to challenge the constitutionality of state laws. ${ }^{13}$ The three-judge district court was a reaction by Progressive Era politicians to the perceived judicial overreach of cases like Ex parte Young, requiring such important suits to be decided by three judges, rather than just one, and for the Supreme Court to be able to promptly hear any appeal. ${ }^{14}$ First established as an intended limit on conservative judicial activism, decades

7. For discussions of the lower court litigation that preceded and culminated in Obergefell, see generally $i d$. at 282-323; Emily Buss, The Divisive Supreme Court, 2016 Sup. CT. Rev. 73, 75.

8. See infra Part I.

9. David P. Currie, The Three Judge District Court in Constitutional Litigation, 32 U. CHI. L. REv. 1, 2 (1964).

10. 410 U.S. $113,121,166$ (1973).

11. We say "strange," here and in the title to the Article, to reference some counterintuitive aspects of the court, including that it came to be seen as friendly to plaintiffs, contrary to the intentions of the Congress that created it. In doing so we channel the classic study, C. VAnn Woodward, The Strange Career of Jim Crow (1955). We thank David Stebenne for suggesting the analogy. See J. Morgan Kousser, The Strange, Ironic Career of Section 5 of the Voting Rights Act, 1967-2007, 86 TEx. L. REv. 667, 674-77 (2008) (also borrowing from Woodward's title in discussing Section 5 of the 1965 Voting Rights Act which, among other things, set up a three-judge district court in the District of Columbia to hear certain aspects of preclearance litigation under Section 5).

12. 209 U.S. 123 (1908).

13. Id. at $161-62$.

14. See infra text accompanying notes $22-36$. 
later, plaintiffs in the Civil Rights Era came to see the court as advancing their agenda. Particularly in the South, some plaintiffs preferred to have their suits decided by three judges, rather than just one possibly hostile judge, with a direct appeal available to a presumably friendly Warren Court..$^{15}$ For these and other reasons, the total number of cases before three-judge district courts, and direct appeals to the Supreme Court, swelled in the 1960s and 1970s. ${ }^{16}$ But at the same time, the court came to be seen by many as administratively burdensome and unnecessary, and Congress in 1976 restricted the jurisdiction of the court to reapportionment cases. ${ }^{17}$ Part I concludes by addressing the relatively little empirical work that has examined the decision-making by and the results of three-judge district court cases.

As described in Part II, this Article breaks new ground and extends prior studies by systematically examining the assumptions of litigation before three-judge district courts through a nationwide database of 885 decisions from those courts that we collected. We focused on the beginning of the modern Civil Rights Era in 1954 (corresponding to the beginning of the Warren Court) to 1976 (when Congress acted to severely restrict the court's jurisdiction). As reported in Part II, our study provides greater and more complete information on the number, types, and results of cases litigated in the court, as well as on the dispositions of appeals to the Supreme Court. Among our findings are that such court decisions were disproportionately in favor of plaintiffs, both in and outside the South, and that there was a high rate of appeal to the Supreme Court.

Part III steps back to consider what difference, if any, the threejudge court, and its direct appeal mechanism, affected jurisprudential developments in civil rights and civil liberties ${ }^{18}$ litigation in the time studied. Would such litigation have been decided, both in lower courts and in the Supreme Court, more-or-less the same in the absence of the three-judge court? Or did the institution of the court have effects on the substance and timing of decisions that possibly would have been

15. See generally infra Part I.

16. See infra text accompanying note 78 .

17. See infra note 59 and accompanying text.

18. This Article addresses both "civil rights" and "civil liberties" cases. The former term usually refers to unequal treatment claims against government action, notably under the Equal Protection Clause of the Fourteenth Amendment, while the latter term typically refers to limits on government power, like those found in the Bill of Rights. See Christopher W. Schmidt, The Civil Rights-Civil Liberties Divide, 12 Stan. J. Civ. Rts. \& Civ. Libs. 1, 3 (2016). As we discuss below, both types of claims were litigated before the three-judge district court during the modern Civil Rights Era. Nonetheless, as reflected in the title of the Article, for convenience we typically only use "civil rights" to refer to both types of claims. We do not use that term to cover other suits in federal court, like those under Title VII of the 1964 Civil Rights Act, that are sometimes referred to as civil-rights actions. 
different had the three-judge district court not existed? To provide some answers to those questions, we address two important areas of law in the period we study: reapportionment and judicial abstention. We also address how direct appeals of these cases impact the Judicial Capacity model, which posits that the sheer number of cases that come to the Supreme Court for review affects the substance of the doctrines developed by the Court.

The final section of Part III, and the conclusion, suggest some lessons that can be drawn from the history of the three-judge district court for the present operation of the federal court system.

\section{Congress, Courts, Litigants, and the Three-Judge District Court}

This Part of the Article sets out the background for our empirical study. We first address the history of the three-judge district court, focusing on its creation, and subsequent modifications, by Congress and its application by federal courts. We then turn to the use of the court by plaintiffs and their lawyers pursuing civil rights claims, especially during the Warren Court, and the initial years of the Burger Court, from 1954 till 1976. We close this Part by summarizing the relatively limited systematic studies that have heretofore been done on decisionmaking by such courts during the years in question.

\section{A. The History of the Three-Judge District Court}

The long-standing tradition of Anglo-American jurisprudence is for trial courts, with rare exceptions, to consist of a single judge (sometimes with a jury empaneled), with review thereafter to multimember appellate courts. ${ }^{19}$ This norm was reflected in the United States in the Judiciary Act of 1789, which established the lower federal courts. ${ }^{20}$ In the following century, federal judges sometimes sat on multimember "circuit courts," but those were eventually abolished not long after the creation of the Courts of Appeals in 1891. ${ }^{21}$

The creation of the modern three-judge district court in 1910 was a distinct exception to the single-judge tradition. ${ }^{22}$ The passage of that

19. Currie, supra note 9 , at 1 .

20. Judiciary Act of 1789 , ch. 20, $\S \S 2-3,1$ Stat. $73,73-74$.

21. See generally Richard H. Fallon, Jr., John F. Manning, Daniel J. Meltzer \& David L. Shapiro, Hart \& Wechsler's The Federal Courts \& the Federal System 29-30 (7th ed. 2015); Currie, supra note 9, at 2. See generally Jonathan Nash \& Michael G. Collins, The Certificate of Division and the Early Supreme Court, 94 S. CAL. L. REV. 733 (2021).

22. FALlON ET AL., supra note 21, at 31. Prior to 1910 Congress twice created three-judge district courts, with direct appeals to the Supreme Court, to hear certain specialized cases. In 1903 Congress established the court to 
law was the culmination of Congressional reaction to Supreme Court decisions that struck down a variety of state regulatory laws passed during the Progressive Era. ${ }^{23}$ One especially notorious decision, though by no means the only one, was Ex parte Young. ${ }^{24}$ That decision held that a Minnesota law regulating railroad rates, similar to the laws of over a dozen other states, was unconstitutional on Due Process grounds, affirming the decision of a federal district judge. But more importantly, it entered the federal courts canon by permitting the railroads to proactively attack the law in federal court and seek injunctive relief against its enforcement. ${ }^{25}$ It accomplished this by holding that the state sovereignty limits established by the Court's interpretation of the Eleventh Amendment could be evaded by the expedient of suing a State officer, like the attorney general, charged with enforcing the law. ${ }^{26} E x$ parte Young and similar cases were subject to severe criticism, perceived as a conservative federal judiciary intruding on the prerogatives of

hear certain types of antitrust suits where injunctive relief was sought, and then in 1906 to hear actions to set aside orders of the Interstate Commerce Commission. Currie, supra note 9, at 2. It appears that the main reasons for these provisions were the perceived importance of the actions being heard, and the need for prompt appellate resolution via a direct appeal to the Supreme Court. See Michael T. Morley, Vertical Stare Decisis and Three-Judge Courts, 108 GEO. L.J. 699, 719-25 (2020) (discussing the 1903 and 1906 laws). However, these laws lack the interesting provenance and controversy associated with the 1910 statute, and did not generate the type or amount of litigation as did the latter, so it is no surprise that they play only minor roles in the story of the three-judge district court. These statutes were repealed in 1974 and 1975, respectively. Id. at $740-43$.

23. The history of the three-judge district court recounted in this paragraph and the next is addressed in greater detail in OwEN M. Fiss, TroubleD Beginnings of the Modern State, 1888-1910, at 211-12 (1993); Barry Friedman, The Will of the People: How Public Opinion Has Influenced the Supreme Court and Shaped the Meaning of The Constitution 184-85 (2009); Currie, supra note 9, at 3-8; Joseph C. Hutcheson, Jr., A Case for Three Judges, 47 HARv. L. REv. 795, 798803 (1934); Michael E. Solimine, Congress, Ex parte Young, and the Fate of the Three-Judge District Court, 70 U. PITT. L. REv. 101, 111-18 (2008) [hereinafter Solimine, Congress, Ex Parte Young].

24. 209 U.S. 123 (1908). There is a lively scholarly debate on how much Ex parte Young doctrinally relied on or departed from case law addressing the then-existing equitable powers of federal courts. For a summary of and contribution to that debate, see James E. Pfander \& Jacob P. Wentzel, The Common Law Origins of Ex parte Young, 72 Stan. L. Rev. 1269, 1282-90 (2020). See also Edward A. Purcell, Jr., Ex parte Young and the Transformation of the Federal Courts, 1890-1917, 40 U. TOL. L. REV. 931 (2009) (situating Ex parte Young in the context of broader changes to federal court litigation and political and policy transformations).

25. Ex parte Young, 209 U.S. at 149-50, 165-66.

26. Id. at 154-55. 
liberal state legislatures seeking to regulate economic relationships. For example, Senator Lee Overman of North Carolina memorably stated on the floor of Congress that when "one little judge stand[s] against the whole State . . . you find the people of the State rising up in rebellion." ${ }^{27}$

Congress considered various measures to overrule or limit Ex parte Young and similar decisions. They ranged from simply prohibiting federal courts from hearing such cases, ${ }^{28}$ to requiring federal judges to take certain additional steps when considering constitutional challenges to state statutes. ${ }^{29}$ Ultimately Congress, led by Senator Overman and others, settled on the more modest response of requiring special procedures, unlike typical federal court suits, to be followed when litigants sought Ex parte Young-type relief against state statutes in federal court. ${ }^{30}$ The statute passed in 1910 required that in such instances a three-judge district court should decide the request for an injunction. ${ }^{31}$ The court consists of the district judge before whom the case was

27. Solimine, Congress, Ex Parte Young, supra note 23, at 115 (quoting 45 Cong Rec. 7256 (1910)). Overman's reference to a "little" federal judge might seem like mere rhetorical flourish, $i d$. at 115-16 n.80 (pointing out that another Senator with apparent sarcasm said that federal judges in his state or elsewhere were not "little"), but it seems to accurately reflect then-extant hostility to merely one federal judge striking down a state statute. See Swift \& Co. v. Wickham, 382 U.S. 111, 118 \& n.13 (1965) (referring to an episode in 1907 where the governor of North Carolina [coincidentally or not, Overman's state] "publicly urged state officials to ignore" a federal judge's decision holding a state statute unconstitutional) (citing S. Ry. Co. v. McNeill, 155 F. 756, 790-91 (1907)).

28. Solimine, Congress, Ex Parte Young, supra note 23, at 113; Hutcheson, supra note 23 , at 804 .

29. William G. Ross, A Muted Fury: Populists, Progressives, And Labor Unions Confront the Courts, 1890-1937, at 74 (1994); Hutcheson, supra note 23, at 804; William F. Duker, Mr. Justice Rufus W. Peckham and the Case of Ex Parte Young: Lochnerizing Munn v. Illinois, 1980 BYU L. REV. 539, 556.

30. Solimine, Congress, Ex Parte Young, supra note 23, at 116-18. This result was of a piece with the eventual demise during this era of other proposed drastic prohibitions or limitations on Supreme Court and lower federal court authority to review state legislation. The adoption of more limited measures like the three-judge district court was due to several factors, including that Progressive critics of federal courts could never agree among themselves on which particular measures to support, and that the Progressives faced formidable opposition from the American Bar Association and other interest groups, which favored leaving the courts alone. For discussion, see FrIEDMAN, supra note 23, at 184-85; Ross, supra note 29, at 58, 6063, 66, 69; Solimine, Congress, Ex Parte Young, supra note 23, at 117-18.

31. Act of June 18, 1910, ch. 309, 36 Stat. 539, 557. Congress in 1911 codified the 1910 Act as $\S 266$ of the Judicial Code. Act of Mar. 3, 1911, ch. 231, $\S 266,36$ Stat. 1087, 1162-63. See generally Morley, supra note 22, at 728-30 (discussing how the 1910 Act was part of the Mann-Elkins Act, and its codification in the Judicial Code the following year). 
initially filed, and two other judges assigned by the Chief Judge of the circuit, at least one of whom must be a circuit judge. ${ }^{32}$ The court's decision could be appealed directly to the Supreme Court which, unlike a case where certiorari applies, the Court ostensibly had to decide on the merits. ${ }^{33}$

The rationales for these procedures were several. Supporters argued that three judges, rather than just one, would give more careful consideration to an important issue like the constitutionality of a state statute. ${ }^{34}$ They also argued that the State and its citizens were more likely to accept a decision by three judges. ${ }^{35}$ Finally, supporters contended that the direct-appeal mechanism would assure that the case would be quickly resolved, by the Supreme Court if necessary, in contrast to a decision by a single judge with lengthy appellate proceedings thereafter possible. ${ }^{36}$

The immediate furor concerning Ex parte Young faded. But over the following seven decades, Congress expanded the coverage of the types of cases governed by the three-judge district court. ${ }^{37}$ The most notable changes were in 1937 and 1965. In the former year, Congress

32. Solimine, Congress, Ex Parte Young, supra note 23, at 113, 115-17.

33. § 266, 36 Stat. at 1163; see infra note 110 and accompanying text.

34. Currie, supra note 9 , at 7 .

35. Id. Thus, Sen. Overman argued that "if three judges declare that a state statute is unconstitutional the people would rest easy under it." Id. (citing 45 Cong. Rec. 7256 (1910)).

36. Michael E. Solimine, The Three-Judge District Court in Voting Rights Litigation, 30 U. MICH. J.L. REF. 79, 84 (1996) [hereinafter Solimine, Voting Rights Litigation]. See generally Solimine, Congress, Ex Parte Young, supra note 23, at 114-18 and sources cited there; sources cited supra note 23. It might seem odd that the statute would provide for prompt review by the Supreme Court when criticism of Supreme Court decisions was in part the driving force of the statute. The apparent incongruity can be explained by the drafters' concern with the inability or difficulty of the losing litigant being able to immediately appeal the grant or denial of a motion for preliminary injunctive relief, as appellate practice stood at the time. Absent the direct review feature, there could be long delays in the lower courts before it might reach the Supreme Court. See Currie, supra note 9, at 8; Solimine, Congress, Ex Parte Young, supra note 23, at 114.

37. Solimine, Congress, Ex Parte Young, supra note 23, at 123-24, 131-32, 134. For overviews of various amendments to the three-judge district court statutes, from 1913 to 1974, see Morley, supra note 22, at 724-43; Solimine, Congress, Ex Parte Young, supra note 23, at 123-25, 131-33, 141 n.199. Under the recodification of federal statutes in 1948, the principal statutes governing which cases would call for a three-judge court were 28 U.S.C. $\S 2281$ (state statutes) and $\S 2282$ (federal statutes), while the direct review provision was at 28 U.S.C. $\$ 1253$. Solimine, Congress, Ex Parte Young, supra note 23 , at $125 \&$ nn.125-27. 
extended the coverage of the court to include suits challenging the constitutionality of federal statutes. ${ }^{38}$ This was a vestige of the President Franklin Roosevelt's storied, and failed, proposal to "pack" the Supreme Court, in response to its rulings finding much New Deal legislation to be unconstitutional. ${ }^{39}$ Part of that discussion was criticism of many federal district judges enjoining the enforcement of New Dealera federal legislation. Critics thought that federal statutes should also receive the protection, as they saw it, of the three-judge district court. ${ }^{40}$

In the Voting Rights Act of 1965, Congress required that certain (mainly Southern) States with a history of discrimination against, and disenfranchisement of, African-Americans must preclear certain changes to election laws with the Department of Justice. ${ }^{41}$ Part of that process permitted those States to petition a three-judge district court convened in the District of Columbia for a declaratory judgment to approve those changes. ${ }^{42}$ That location was chosen due to the judges in the District having experience in dealing with other putatively similar, specialized areas of administrative law, and because it was thought that judges there would be less hostile to enforcing the Act as compared to judicial colleagues in the affected states. ${ }^{43}$

The 1965 expansion of the coverage of three-judge district courts ironically came at a time when increasing criticism of the court in the

38. Solimine, Congress, Ex Parte Young, supra note 23, at 124; Morley, supra note 22 , at 734 .

39. Solimine, Congress, Ex Parte Young, supra note 23, at 124.

40. Barry Cushman, The Judicial Reforms of 1937,61 WM. \& MARY L. Rev. 995, 998 (2020); Solimine, Congress, Ex Parte Young, supra note 23, at 124-25. For further discussion of the 1937 statute, see generally Cushman, supra; Comment, The Three-Judge Federal Court in Constitutional Litigation: A Procedural Anachronism, 27 U. CHI. L. Rev. 555, 561-63 (1960) [hereinafter Chicago Comment].

41. Solimine, Congress, Ex Parte Young, supra note 23, at 132.

42. Id.

43. Michael E. Solimine, Rethinking District of Columbia Venue in Voting Rights Preclearance Actions, 103 Geo. L.J. Online 29, 31-32, 36 (2014). Aside from federal judges in the District of Columbia not being in the mostly southern states targeted by the preclearance provision, those judges were not subject to the courtesy typically afforded Senators during the appointment process for judges who serve in a State. Id. at 31. For further discussion of this aspect of the Voting Rights Act (VRA), see $i d$. at 3133. Despite contemporary decisions narrowly construing the relevant statutes, see infra note 50, the Supreme Court expansively interpreted the coverage of the three-judge district court in the preclearance provision, given what it called the "extraordinary effect" Congress intended by preclearance, and given that the "clash between federal and state power and the potential disruption to state government are apparent." Allen v. State Bd. of Elections, 393 U.S. 544, 562-63 (1969) (Warren, C.J.); see also id. at 582 n.1 (Harlan, J., concurring in part and dissenting in part) (agreeing with majority on the coverage issue). 
legal community was already well underway. A confluence of reasons severely undermined the continued existence of the court. First was the large number of suits in the 1960s, continuing into the 1970s, that required the convening of three-judge district courts, reaching several hundred each year during those decades. ${ }^{44}$ This was accompanied by the awkward administrative burdens of assembling three federal judges to hear and decide a trial. ${ }^{45}$ Similarly, these cases inevitably generated many direct appeals to the Supreme Court, reaching twenty or more decided on the merits each Term during the two decades mentioned. ${ }^{46}$ The Court considered these appeals a burden compared to the rest of the Court's docket, which came up on discretionary certiorari jurisdiction. This was despite the fact that, while the direct-appeal statute seemed to require the Court to decide each case on its merits, the Court resolved a significant number of such appeals each Term by summary affirmances or reversals. ${ }^{47}$ Indeed, in 1974, the Court observed that it typically summarily disposed of between two-thirds and three-fourths of such appeals. ${ }^{48}$

At the same time, many policymakers felt that the original purpose of the court, to limit single district judges holding state statutes unconstitutional, was either no longer necessary or at best of limited relevance

44. Solimine, Congress, Ex Parte Young, supra note 23, at 126; see infra Table 1.

45. See infra text accompanying note 235 .

46. Solimine, Congress, Ex Parte Young, supra note 23, at 137; see infra Table 2. See infra Part II(B)(1) for more documentation and discussion of the increased caseload at the district and Supreme Court level. The fact that there was a sharp increase in such cases in the late 1960s to the mid-1970s likely helped the cause of the opponents of the court.

47. See infra note 110 and accompanying text; Solimine, Congress, Ex Parte Young, supra note 23, at 127 \& n.134; Gonzalez v. Automatic Emps. Credit Union, 419 U.S. 90, 99 n.17 (1974). During this time some of the direct appeals were also from decisions of district judges sitting alone or from state supreme courts. Those appeals were not affected by the legislation in 1976, but were almost totally abolished by legislation in 1988 . See FALlON ET AL., supra note 21, at 1090 (discussing the impact of Act of Aug. 12, 1976, Pub. L. No. 94-381, 90 Stat. 1119); Supreme Court Case Selections Act of 1988, Pub. L. No. 100-352, 102 Stat. 662. By the 1970s the Court, sometimes confusingly to itself, lower courts, and the bar, held that even summary affirmances (with no accompanying opinion) were technically "on the merits," and thus ostensibly had a precedential effect. For further discussion, see infra notes 112, 166 and accompanying text.

48. Gonzalez, 419 U.S. at 99 n.17 (first citing William O. Douglas, The Supreme Court and Its Case Load, 45 Cornell L.Q. 401, 410 (1960) (providing data from the decisions in volumes 350 through 360 of the U.S. Reports; fifty-two of such appeals were argued and decided by opinion, while eighty were summarily disposed of); and then citing Note, The Freund Report: A Statistical Analysis and Critique, 27 Rutgers L. Rev. 878, 902-03 (1974) (providing data from the 1972 Term, indicating that 89 of 132 appeals (67\%) from three-judge district court decisions were summarily affirmed)). 
for a small number of cases. The normal appellate process, with review as of right by a circuit court and discretionary review thereafter by the Supreme Court, was considered adequate (as in the vast majority of cases) to superintend the work of district judges hearing constitutional challenges to federal statutes. ${ }^{49}$

A formidable array of high-profile persons and institutions in the legal community came to press these rationales in calling on Congress to abolish or limit the scope of the court. These included the Supreme Court, overtly making such arguments in Court opinions or in other legal writings $;{ }^{50}$ the American Law Institute, in its influential Study of the Division Between State and Federal Courts, suggested by Chief Justice Earl Warren and issued in $1969{ }^{51}$ prominent scholars, such as

49. Michael E. Solimine, Ex Parte Young: An Interbranch Perspective, $40 \mathrm{U}$. TOL. L. REV. 999, 1005 (2009). For further discussion of the points in this paragraph, see Solimine, Congress, Ex Parte Young, supra note 23, at 134-37, and sources cited there.

50. Solimine, Congress, Ex Parte Young, supra note 23, at 139-40, 139 n.188. Chief Justice Burger argued for the abolition of the court in published writings, as did a study issued by the Federal Judicial Center in 1972 that he had commissioned. Id. at 139. Likewise, the Court as a whole in its opinions was overtly lukewarm to the institution of the court during the Warren and Burger eras, both in its statutory interpretation limiting the coverage of the court, and in lamenting the burden placed on the Court by mandatory direct appeals. Id. at 140-41; see, e.g., Swift \& Co. v. Wickham, 382 U.S. 111, 128-29 (1965) (Harlan, J.) (holding that statutory mandate to convene the court when state statute is constitutionally challenged did not cover Supremacy Clause cases, where the state law was alleged to conflict with a federal statute, and basing decision in part on concerns of judicial administration); Gonzalez, 419 U.S. at 98-101 (Stewart, J., for a unanimous court) (holding that when a three-judge district court denies an injunction not on the merits but on a ground (here, lack of standing) that would have justified the court dissolving itself, any appeal should be to the Court of Appeals, not a direct appeal to the Supreme Court, and similarly invoking the asserted need of "minimizing the mandatory docket of this Court in the interests of sound judicial administration"). Both decisions cited scholarly commentary on the three-judge district court, much of it calling for the abolition or limitations on the court. Swift $\&$ Co., 382 U.S. at 116 n.8, 124 n.20; Gonzalez, 419 U.S. at 96 n.14, 97 n.15, 98 n.16. But see MTM, Inc. v. Baxley, 420 U.S. 799, 808 (1975) (Douglas, J., dissenting) (citing Gonzalez as an example of the "Court's hostility to threejudge courts," though acknowledging that he had joined in that opinion).

51. Study of the Division of Jurisdiction Between State and Federal Courts 1, 316-17, 323, 325 (Am. L. Inst. 1969) [hereinafter ALI STudy] (arguing that the court should be abolished for constitutional challenges to federal statutes, but left intact for such challenges to state statutes and constitutional provisions, albeit only when the defendant requests that one be convened). See Sidney B. Jacoby, Recent Proposals and Legislative Efforts to Limit Three-Judge Court Jurisdiction, 26 CASE W. RsRV. L. REv. 32, 32-37 (1975) (discussing proposals of the ALI STUDY regarding the three-judge district court). For further discussion of the origins of the 
Charles Alan Wright ${ }^{52}$ and David Currie $;^{53}$ and a diverse array of wellknown federal judges from across the political spectrum, such as Henry Friendly ${ }^{54}$ and J. Skelly Wright. ${ }^{55}$ There were defenders of the status quo, such as the NAACP, arguing that the court was needed to combat the possible parochialism of federal judges sitting alone, especially in sensitive civil rights cases $^{56}$ But the opposition to the proposed curtailment failed to gain traction, especially after their arguments were considered and ultimately rejected by the judiciary committees in Congress. Especially notable in this regard was the support for change by the well-known liberal Democrat on the House Judiciary Committee, Representative Robert Drinan, who argued that civil-rights enforcement by the federal courts would not suffer by abolishing or limiting the ambit of the court..$^{57}$

Bills to limit or abolish the three-judge district court were introduced in Congress starting in 1971, and extensive hearings were held over the next several years. ${ }^{58}$ The proposals came to a head in 1976. That year, Congress enacted legislation which abolished the court, save for suits dealing with the "apportionment" of the districts for members of Congress, and for state legislatures. ${ }^{59}$ For our purposes, two aspects

ALI study, its other recommendations, and their reception in Congress, see Diego A. Zambrano, Federal Expansion and the Decay of State Courts, 86 U. CHI. L. REv. 2101, 2120-22 (2019).

52. Admiralty Jurisdiction, United States as a Party, General Federal Question Jurisdiction, Three-Judge Courts: Hearing on S.1876 Before the Subcomm. on Improvements in Jud. Mach. of the S. Comm. on the Judiciary, 92nd Cong. 772-74 (1972) (statement of Professor Charles Alan Wright, School of Law, University of Texas).

53. See Currie, supra note 9 , at $75-76$.

54. Hearing on S.1876, supra note 52, at 749 (statement of Judge Henry Friendly).

55. Id. at 791 (statement of Judge Skelly Wright).

56. See H.R. Rep. No. 94-1379, at 13-14 (statement of Rep. Robert Drinan). See also MTM, Inc. v. Baxley, 420 U.S. 799, 808 (1975) (Douglas, J., dissenting) ("[A]t least some observers believe the three-judge court to be an important institution for litigants such as civil rights and welfare plaintiffs. Three judges may well display more sensitivity to national policies and perspectives than would a single judge, and when three judges decide in favor of a minority or an unpopular group their decision is likely to inspire more respect than would the decision of a single judge."). For a particularly thorough argument in favor of leaving the court intact, see Wendy G. Singley, Note, The Abolition of Three-Judge Courts: Too High a Price for Judicial Efficiency?, 4 Hofstra L. REV. 355, 381 (1976).

57. For further discussion of and citation to the authorities mentioned in the paragraph, see Solimine, Congress, Ex Parte Young, supra note 23, at 143-44, 147-48.

58. Id. at 141-43 (summarizing the hearings in Congress).

59. Act of Aug. 12, 1976, Pub. L. No. 94-381, 90 Stat. 1119 (codified in part at 28 U.S.C. $\S 2284)$. 
of the legislation are especially noteworthy. One is the reapportionment exception, which covered canonical cases like Baker $v$. Carr $^{60}$ and its "one-person-one-vote" progeny, as well as other suits involving statewide apportionment. ${ }^{61}$ The legislative record is not crystal clear on why Congress created this exception; the Committee reports on the final legislation simply refers, in an unelaborated way, to the "importance" of those types of cases. ${ }^{62}$ Among the reasons advanced by policymakers was that it was thought such cases, dealing with court review of the decennial drawing of district lines (typically by the state legislature, sometimes in conjunction with the governor and other elected officials), were particularly controversial ${ }^{63}$ and subject to possible explicit or implicit partisan decision-making by federal judges, and hence more appropriate for decision by three judges.$^{64}$ Indeed, even some stalwart critics of the general notion of three-judge district courts had for that

60. 369 U.S. 186, 187-88, 209 (1962) rev'g 179 F. Supp. 824 (M.D. Tenn. 1959) (three-judge court).

61. See, e.g., Reynolds v. Sims, 377 U.S. 533, 560, 568 (1964) (applying the one-person one-vote rule to state legislative apportionment).

62. Solimine, Congress, Ex Parte Young, supra note 23, at 144.

63. For a particularly astute student article making the point, see Note, The Three-Judge Court Reassessed: Changing Roles in Federal-State Relationships, 72 YALE L.J. 1646, 1660 (1963) [hereinafter Three-Judge Court Reassessed] (observing that in reapportionment cases, a "federal court is likely to engage in a prolonged, not always harmonious, dialogue with the state legislature," and arguing that a "three-judge court would be appropriate because of its greater dignity and ability to elicit a compliant response."). Even a generation later the Supreme Court has emphasized that redistricting is "primarily the duty and responsibility of the state" and that "federalcourt review of districting legislation represents a serious intrusion on the most vital of local functions." Abbott v. Perez, 138 S. Ct. 2305, 2324 (2018) (quoting Miller v. Johnson, 515 U.S. 900, 915 (1995) (internal question marks and alterations omitted)); see also Rucho v. Common Cause, 139 S. Ct. 2484, 2496-97, 2507 (2019) (emphasizing that while federal courts may adjudicate one-person-one-vote and racial gerrymandering challenges to apportionments, historically federal courts have deferred to the political process); Thomas v. Reeves, 961 F.3d 800, 808 (5th Cir. 2020) (en banc) (Costa, J., concurring) (the 1976 Act "retained the procedure for a small set of important cases: constitutional challenges to redistricting for congressional and state legislative seats, then-recent phenomena in the aftermath of the revolutionary one person, one vote line of cases").

64. See Joshua A. Douglas, The Procedure of Election Law in Federal Courts, 2011 Utah L. Rev. 433, 442-44, 462-63 (discussing the ideological concerns of single-judge and three-judge district courts in the context of election law); Joshua A. Douglas \& Michael E. Solimine, Precedent, ThreeJudge District Courts, and the Law of Democracy, 107 Geo. L.J. 413, 444, 451 (2019) (describing the important virtues of three-judge district courts as "impartiality and legitimacy"). 
reason argued for such an exception. ${ }^{65}$ By the same token, it was also thought at the time that this exception would be a narrow one, and not generate the large number of cases that was the bane of the court in the previous two decades. ${ }^{66}$

The other notable aspect of the 1976 legislation is, in the end, its relatively uncontroversial nature and the wide support (or perhaps better put, limited opposition) it ultimately received. There were Democratic majorities in both houses of Congress at that time, unafraid to respond to Republican Presidents and, it might be thought, sympathetic to the concerns of defenders of the status quo like the NAACP. ${ }^{67}$ But as already noted, supporters of eliminating or limiting the court started with the Justices of the Supreme Court, as revealed in their decisions, and continued with prominent jurists, scholars, and interest groups spanning the political spectrum. The reasons for drastically limiting the jurisdiction of the three-judge district court were framed almost exclusively in efficiency and administrative concerns. It appears that this was thought to be a mostly technical, nonpolitical correction, and Congress was deferring to the presumed expertise of federal judges and other high-profile policymakers from the legal community. ${ }^{68}$ The opponents of the change were far fewer in number and failed in their effort to turn the debate into a more substantive one. ${ }^{69}$

65. See Solimine, Congress, Ex Parte Young, supra note 23, at 137, 137 n.176-77 (citing to scholarly commentary which uniformly criticized the court but argued that it is still appropriate in controversial cases like racial discrimination or reapportionment).

66. For further discussion of and citation to the points made in this paragraph, see Solimine, Congress, Ex Parte Young, supra note 23, at 138, 144-45. An illuminating contemporary account making many of these points, by the then-Deputy Counsel to the Senate Judiciary Committee, is Michael J. Mullen, Improving Judicial Administration by Repealing the Requirements for Three-Judge District Courts, 20 CATH. LAw. 372, 374-76 (1974). Our account also greatly benefitted from further discussions with Mr. Mullen, elaborating on the legislative history of the 1976 Act. See E-mail from Michael J. Mullen, Sr. to Michael E. Solimine, (July 18, 2019 10:01 PM) (on file with author) [hereinafter Mullen E-mail].

67. Congress Profiles: 94th Congress, U.S. House of Representatives Off. OF THE HiSTORIAN https://history.house.gov/Congressional-Overview/ Profiles/94th/ [https://perma.cc/8V5X-Q2D3] (last visited Jan. 2, 2022); Party Division, U.S. SENATE https://www.senate.gov/history/partydiv.htm [https://perma.cc/7587-EPA6] (last visited Jan. 2, 2021); see also Solimine, Congress, Ex Parte Young, supra note 23, 147-148 (discussing the Congressional majorities and their opposing views to the NAACP).

68. See H.R. ReP. No. 104-179, at 9-12 (1995) (discussing that Congress originally limited the jurisdiction of three judge district courts because they were a "serious drain upon the federal judicial system" and "administratively complicated to convene and conduct").

69. For further discussion of these points, see Solimine, Congress, Ex Parte Young, supra note 23, at 146-48, 151-53. Chief Justice Burger took an 
While Congress downsized the three-judge district court in 1976 to the reapportionment exception, its use in the preclearance provision in the Voting Rights Act was left intact. ${ }^{70}$ Since then, Congress has periodically considered proposals to require such courts to be convened to hear certain types of suits. ${ }^{71}$ It has required that constitutional challenges to certain federal statutes be initially brought before such a court, with the most notable example being the Bipartisan Campaign

especially active role in urging Congress to eliminate or substantially limit the jurisdiction of the three-judge district court, and to eliminate direct appeals. See, e.g., Warren E. Burger, Annual Report on the State of the Judiciary, 62 A.B.A. J. 443, 443-44 (1976); Warren E. Burger, The Condition of the Judiciary: Year-End Report, 20 Res Gestae 76, 78 (1976). On the likelihood of Congress adopting the recommendations of the Chief Justices, as revealed in their Annual Reports, see generally, Richard L. Vining Jr., Teena Wilhelm \& David A. Hughes, The Chief Justice as Effective Administrative Leader: The Impact of Policy Scope and Interbranch Relations, 100 Soc. SCI. Q. 1358, 1358 (2019). The 1976 legislation is particularly striking given that Democratic majorities in both chambers in Congress at the time were not reticent in passing laws that aided plaintiffs in civil-rights actions. See Stephen B. Burbank, Sean Farhang \& Herbert M. Kritzer, Private Enforcement, 17 Lewis \& ClarK L. REv. 637, 651-52 (2013) (discussing how Congress during this period enacted private rights of actions and fee-shifting statutes to facilitate enforcement of federal law).

70. The use of the court for preclearance actions became dormant after the Court held that the separate coverage formula of the preclearance provision was unconstitutional. Shelby Cnty. v. Holder, 570 U.S. 529, 557 (2013).

71. See Solimine, Congress, Ex Parte Young, supra note 23, at 149 (discussing several examples, including one to require the court be convened to hear constitutional challenges to the passage of state referenda). Other recent, unenacted proposals include three-judge district courts to hear any constitutional challenges to the Affordable Care Act of 2010, see 155 ConG. REC. S13791-92 (daily ed. Dec. 22, 2009) (submitted by Sen. Orrin Hatch), to a proposed bill to limit the ability of President Trump to fire Special Counsel Robert Mueller, see Special Counsel Independence and Integrity Act, S. 2644, 115th Cong. § 2(e)(2) (2018), or to federal statutes where a national or universal injunction is sought, see Bradford Mank \& Michael E. Solimine, State Standing and National Injunctions, 94 Notre Dame L. Rev. 1955, 1980-81 (2019); Howard M. Wasserman, Congress and Universal Injunctions, 2021 CARDOZO L. REV. DE•NOVO 187, 19798; Szymon S. Barnes, Note, Can and Should Universal Injunctions Be Saved?, 72 VAND. L. REV. 1675, 1709-12 (2019); see also Thomas P. Schmidt, Judicial Minimalism in the Lower Courts, 108 VA. L. REV. (forthcoming 2022), https://ssrn.com/abstract=3914201 (manuscript at 71-72) (following example of a three-judge district court, arguing that nationwide injunctions should only go into effect when issued by more than one judge, given the "general pattern of the judicial system that the more legally consequential a decision is, the more judges must concur in it.") (footnote omitted). 
Reform Act of 2002 (McCain-Feingold). ${ }^{72}$ Between such cases and the reapportionment exception, the three-judge district court generates a relatively small number of cases. But on election law issues, they have attention and influence disproportionate to their numbers in both district courts and on direct appeals to the Supreme Court. ${ }^{73}$ The notion of three judges being more appropriate to hear certain types of highprofile cases in the first instance continues to have resonance in some quarters.

\section{B. The Three-Judge District Court in the Civil Rights Era}

From the near demise of the three-judge district court, we return to the era when there were large numbers of cases in those courts, both at the trial level and on direct appeal to the Supreme Court. That time, which we and many others label the Civil Rights Era, ${ }^{74}$ is for us bookended by the advent of the Warren Court (conventionally associated with the appointment of Earl Warren as Chief Justice) in 1954 and the statutory diminution of the three-judge district court in $1976 .{ }^{75}$ Those years were marked by much federal-court litigation concerning, among

72. For further discussion of the use of the court in challenges to the BCRA, and of other discrete instances where Congress has required the use of a three-judge district court since the 1976 legislation, see Michael E. Solimine, The Fall and Rise of Specialized Federal Constitutional Courts, 17 U. PA. J. Const. L. 115, 128-29 (2014).

73. Douglas \& Solimine, supra note 64, at 419; Richard L. Hasen, Election Law's Path in the Roberts Court's First Decade: A Sharp Right Turn but with Speed Bumps and Surprising Twists, 68 StAN. L. Rev. 1597, 162022 (2016).

74. See generally Michael J. Klarman, From Jim Crow to Civil Rights: The Supreme Court and the Struggle for Racial Equality (2004) (discussing the history of the Civil Rights Era through the context of Supreme Court decisions starting in the 1950s and ending in the 1970s). We concede that our use of the term "Civil Rights Era" for the 1954-1976 period is for convenience and is arbitrary and imprecise. There are of course no formal beginning and ending dates for the era. Some might trace the beginning to the 1940 s, and its informal end to the early years of the Nixon Administration, as it in particular concerns legislation and court decisions dealing with race relations. See, e.g., JAmes T. PATterson, Grand Expectations: The United States, 1945-1974, at 26, 735 (1996); Christopher W. Schmidt, Legal History and the Problem of the Long Civil Rights Movement, 41 LAw \& Soc. INQUIRY 1081, 1081-82 (2016).

75. Three-judge district court litigation prior to 1954 has been subject to less systematic study. For some discussions of that period, see Felix Frankfurter, Distribution of Judicial Power Between United States and State Courts, 13 Cornell L.Q. 499, 518 (1928) (discussion of such litigation and the direct appeals to the Supreme Court from 1913 to 1926); Hutcheson, supra note 23, at 813-25 (discussion of such litigation from 1910 to 1934); Mila Sohoni, The Lost History of the "Universal" Injunction, 133 HARV. L. REv. 920, 959-62, 970-73 (2020) (discussing Pierce v. Society of Sisters, 268 U.S. 510 (1925), and other Supreme Court cases on direct appeal from three-judge district courts). 
other things, the development and application of the Bill of Rights, and of the Due Process and Equal Protection Clauses of the Fourteenth Amendment. Many of those suits involved challenges to state statutes and provisions of state constitutions, requiring the convening of threejudge district courts. ${ }^{76}$

The growth in the caseload at the district court level is documented in Table 1. As it indicates, for much of the 1950s, about fifty threejudge district courts were convened per year. ${ }^{77}$ Those numbers rapidly rose in the early 1960s, reaching 215 by 1969, and rising still further to a high of 320 in 1973. It steadily declined to 208 cases in 1976, and it fell sharply thereafter. ${ }^{78}$ In most years, over one-half of those cases were civil rights and reapportionment actions. ${ }^{79}$ The growth in direct appeals from such courts decided on the merits by the Supreme Court is documented in Table $2 .{ }^{80}$ As shown there, the number of cases decided

76. For further discussion of the reasons for the large numbers of such cases during the period in question, see infra Part II(B).

77. As Table 1 indicates, the source of the data is various issues of the Annual Report of the Administrative Office of the United States Courts [hereinafter Annual Report]. The Annual Report refers to "hearings," not simply filed suits or cases. The terms are not synonymous: a three-judge district court might be convened and terminated without a hearing as such being held, and there might be multiple hearings in one case. See Solimine, Voting Rights Litigation, supra note 36, at 90-91. Nonetheless, for convenience we will use the terms more or less interchangeably hereafter.

78. As late as 1977 and 1978 there were 112 and 67 cases, respectively, because the statutory change did not apply retroactively. See Act of Aug. 12, 1976, Pub. L. No. 94-381, §7, 90 Stat. 1119, 1120 (codified in part at 28 U.S.C. $\S 2284$ ) (indicating that the "Act shall not apply to any action commenced on or before the date of enactment [Aug. 12, 1976].").

79. See infra Table 1. The numbers are considerable even taking into account the forty to sixty appeals, on average each year, from orders of the Interstate Commerce Commission (ICC). Judicial Review of the Interstate Commerce Commission: Hearing on S. 663 and H.R. 785 Before the Subcomm. on Crime of the H. Comm. on the Judiciary, 93rd Congress 30 tbl.40 (Dec. 10, 1974). Congress abolished that path to appeal ICC orders in 1975. See note 22 supra. The distinction between the remaining types of cases (i.e., civil rights, reapportionment, and others) was reported in the Annual Report, starting in 1963. However, the Annual Report did not further define the categories, and the staff that prepared the tables relied on reports from clerks of U.S. District Courts. See Solimine, Voting Rights Litigation, supra note 36 , at 91 n.78 (citing correspondence with staff at the Administrative Office). Presumably District Court clerks defined "civil rights" similar to how we do, see note 18 supra, as referring primarily to discrimination cases under the Equal Protection Clause or other laws. But it may have included some or many "civil liberties" cases, involving the First and other Amendments. So the numbers in Table 1 should be compared to our data set with caution.

80. In Table 2, the totals of three-judge district-court cases decided on direct appeal by the Supreme Court, per Term, is taken from the U.S. Supreme Court Judicial Database Project. See Solimine, Voting Rights Litigation, 
on the merits (i.e., typically after briefing and oral argument) ranged from five to twelve during the 1954 through 1960 Terms, but picked up considerably after that. It ranged from a low of fifteen in the 1965 Term to highs of fifty-nine and sixty-five in the 1972 and 1976 Terms, respectively. The average from the 1961 through 1976 Terms was approximately thirty-eight, which accounted for nearly $25 \%$ of all of the cases decided on the merits by the Court during these Terms. ${ }^{81}$

Most of these cases, at the trial level or on direct appeals to the Supreme Court, involved constitutional challenges to state statutes or constitutional provisions, and many involved civil-rights or civilliberties issues. ${ }^{82}$ And here lies the basis of the apparently strange career of the three-judge district court referenced in the title of this Article. Recall that Congress originally established the court, in part, as a limit on federal judicial invalidation of state regulatory legislation during the Progressive Era. It was thought that three judges were less likely to issue injunctions invalidating such legislation than merely one. Litigation during the opening years of the Civil Rights Era turned this narrative on its head. In at least some cases, plaintiffs' attorneys in civil-rights cases preferred to litigate before three-judge district courts. They felt that at least two out of three judges, especially in the Deep

supra note 36, at 106 n.166 (citing Memo from James L. Walker to Michael E. Solimine (Jan. 17, 1996) (on file with the University of Michigan Journal of Law Reform)). That source is now available as the "Supreme Court Database." The Supreme Court Database, WAsH. U.L., www.scdb.wustl.edu [https://perma.cc/F7YN-HZ5H] (last visited Sept. 10 2021). The totals used to calculate the percentages in Table 2 of all Court decisions on the merits, per Term, are taken from Lee Epstein, Jeffrey A. Segal, Harold J. Spaeth \& Thomas G. Walker, The Supreme Court Compendium: Data, Decisions, And Developments 88-89 tbl.2-2 (6th ed. 2015) (including both signed and per curiam opinions). Another source of data for such cases on the Supreme Court's docket are the statistical compilations in the annual November issues of the Harvard Law Review. See The Three-Judge Court Reassessed, supra note 63, at 1655 \& n.53; Note, The Three-Judge District Court: Scope and Procedure Under Section 2281, 77 HARv. L. REv. 299, 304 (1963) [hereinafter Harvard Note]. These separate sources of data may not yield identical figures for any given year or Term.

81. Solimine, Voting Rights Litigation, supra note 36, at 106 n.168, 107, 138. On the other hand, these numbers do not indicate the number of summary affirmances or reversals each Term. For discussion of the latter dispositions, see infra notes 110-12 and accompanying text.

82. Solimine, Congress, Ex Parte Young, supra note 23, at 126; see also Arthur D. Hellman, The Supreme Court and Civil Rights: The Plenary Docket In the 1970's, 58 OR. L. REV. 3, 3, 60 n.231 (1979) (documenting increase in civil rights cases on Supreme Court docket from 1959 through 1976 and attributing increase in part to appeals from three-judge district courts). 
South, were - all things being equal - more likely to hold for their position than one possibly recalcitrant district judge acting alone. ${ }^{83}$ And no matter how the three-judge court held, there would be a direct appeal to the Supreme Court, which, starting with Chief Justice Warren's appointment in 1954 and the holding in the same year in Brown $v$. Board of Education, ${ }^{84}$ was considered a hospitable forum for civil rights plaintiffs. This process would be, in theory, faster than the usual practice of an appeal to the court of appeals, followed by a possible discretionary writ of certiorari to the Supreme Court. ${ }^{85}$

There is considerable evidence from the chroniclers of the storied school desegregation litigation, and other civil rights litigation mainly in southern states, supporting this account. ${ }^{86}$ This is not to say that all three-judge district court decisions in such litigation were in favor of plaintiffs. Consider Brown itself, which reversed a three-judge court decision. ${ }^{87}$ But other well-known civil-rights cases illustrate the strategy

83. See Solimine, Congress, Ex Parte Young, supra note 23, at 128-29 \& n.140 (citing several examples of Civil Rights Era cases decided before three judge district courts).

84. 347 U.S. 483, 495 (1954).

85. See generally Solimine, Congress, Ex Parte Young, supra note 23, at 127.

86. Some of these accounts are more journalistic or anecdotal, see, e.g., JACK Bass, Unlikely Heroes 19 (1981); Jack Greenberg, Crusaders in the Courts: How a Dedicated Band of Lawyers Fought for the Civil Rights Revolution 69-70 (1994), while others are more systematic, see, e.g., J.W. Peltason, Fifty-Eight Lonely Men: Southern Federal Judges And School Desegregation 108-09 (1961); Robert J. Steamer, The Role of Federal District Courts in the Segregation Controversy, 22 J. PoL. 417, 424-26 (1960); Leanna Lee Whitman \& Michael Hayes, Lou Pollak: The Road to Brown v. Board of Education and Beyond, 158 Proc. Am. Phil. SoC'y 31, 44-45 (2014). This is not to say that plaintiffs choose three-judge district courts in lieu of filing before single district judges. While throughout the history of the three-judge district court, it was often unclear when such a court needed to be convened, see Currie, supra note 9, passim, the statute on its face mandated convening of the court when plaintiffs sought to enjoin a statewide law as unconstitutional. In those circumstances, the court would be convened whether plaintiffs (or defendants) desired that as a litigation strategy or not. There were unclear exceptions to this mandate, such as when the state statute was "clearly" unconstitutional. Id. at 64-65. Nonetheless, some civil-rights plaintiffs appear to have filed suit in the first instance largely because they knew a three-judge district court would be convened. See GreEnBERG, supra, at 126-27 (discussing plaintiffs' litigation strategy in Brown); Solimine, Congress, Ex Parte Young, supra note 23 , at 128 n.137 (discussing the point more generally).

87. 347 U.S. 483 (1954), rev'g 98 F. Supp. 797, 800 (D. Kan. 1951) (threejudge court). See also two of the other three cases jointly decided by the Supreme Court in Brown, Briggs v. Elliott, 98 F. Supp. 529, 536-37 (E.D.S.C. 1951) (three-judge court), and Davis v. Cnty. Sch. Bd., 103 F. Supp. 337, 340 (E.D. Va. 1952) (three-judge court). 
of litigants favoring such courts. ${ }^{88}$ And there is anecdotal evidence in some high-profile cases not involving racial discrimination, both before ${ }^{89}$ and during (or shortly after) the Civil Rights Era, of three-judge district courts holding for plaintiffs. Consider, from the constitutional-law and federal-courts canons, such cases as Roe v. Wade ${ }^{90}$ San Antonio School District v. Rodriquez ${ }^{91}$ or Younger v. Harris.$^{92}$

Do more systematic studies support the model of three-judge district courts being favorable forums for litigants challenging state laws? To date, a few such studies provide at least some support for the proposition. Two studies, covering several hundred published decisions from 1963 through 1968, compared constitutional litigation before single district judges and three-judge district courts, and found that the latter were more likely to find for plaintiffs than the former. ${ }^{93}$ Another study, focusing on school desegregation litigation in the wake of Brown, similarly found that three-judge district courts were more likely to hold for

88. See, for example, litigation involving the famed Montgomery bus boycott, Browder v. Gayle, 142 F. Supp. 707, 711 (M.D. Ala. 1956) (per curiam) (three-judge court), aff'd, 352 U.S. 903 (1956). Of particular interest is the dissenter in the district court in Browder, who criticized the majority for taking what he saw as an activist position in over-broadly interpreting Supreme Court decisions to hold for the plaintiffs. Id. at 718 (Lynne, J., dissenting). The precise issue that split the court, as recognized by the majority, was whether Brown expressly overruled the separate-but-equal doctrine of Plessy v. Ferguson, 163 U.S. 537 (1896) outside the education context. Browder, 142 F. Supp. at 717. For examples of other three-judge district courts holding for plaintiffs in desegregation cases in the 1950s and 1960s, see Solimine, Congress, Ex Parte Young, supra note 23, at 127-29.

89. See, e.g., Pierce v. Soc'y of Sisters, 268 U.S. 510, 528-31, 536 (1925) (enjoining state law mandating public schooling), aff'g 296 F. 928, 931 (D. Or. 1924) (three-judge court); W. Va. State Bd. of Educ. v. Barnette, 319 U.S. 624, 625-26, 628-29, 642 (1943) (enjoining state law requiring students to salute the flag or recite the Pledge of Allegiance), aff'g 47 F. Supp. 251, 252 (S.D.W. Va. 1942) (three-judge court).

90. 410 U.S. 113, 166 (1973) (holding unconstitutional laws forbidding abortion), aff'g 314 F. Supp. 1217, 1217, 1219 (N.D. Tex. 1970) (three-judge court).

91. 411 U.S. 1, 58-59 (1973) (upholding use of property tax to finance public schools), rev'g 337 F. Supp. 280, 280-81 (W.D. Tex. 1971) (per curiam) (three-judge court).

92. 401 U.S. 37, 53 (1971) (requiring federal courts to abstain when state criminal defendant could raise federal constitutional claims in state prosecution), rev'g 281 F. Supp. 507, 507-08 (C.D. Cal. 1968) (three-judge court).

93. Eleanor C. Main \& Thomas G. Walker, Choice Shifts and Extreme Behavior: Judicial Review in the Federal Courts, 91 J. Soc. PSYch. 215, 218, 220 (1973) (in 521 cases, individual judges held $45 \%$ of statutes unlawful, and three-judge district courts held $67 \%$ of statutes unlawful); Thomas G. Walker \& Eleanor C. Main, Choice Shifts in Political Decisionmaking: Federal Judges and Civil Liberties Cases, 3 J. Applied Soc. Psych. 39, 42-43 (1973) (in 1995 cases, comparable percentages were $30 \%$ and $65 \%$, respectively). 
plaintiffs than single judges. ${ }^{94} \mathrm{~A}$ third study focused on decisions of three-judge district courts in the Fourth and Fifth Circuits from 1963 through 1975 and found marked plaintiff success at the trial level and when those cases were appealed to the Supreme Court. ${ }^{95}$

All of these studies remain interesting and valuable for purposes of this Article, but they have limitations as well. They variously do not cover all of the years of the Civil Rights Era (however one defines that term); do not cover all types of cases, by subject-matter, that were litigated before three-judge district courts in the relevant time period; or are limited to certain regions of the country. To obtain a more comprehensive perspective on three-judge district court litigation, at both the district and Supreme Court levels, a broader search for and coding of decisions was necessary. The next section of the Article undertakes that task.

\section{Empirical Study of Three-Judge District Court Decisions in Civil Rights Cases, 1954-1976}

This Part of the Article presents our empirical study of three-judge district court decisions, in cases challenging state practices, during the Civil Rights era and its immediate aftermath, until Congress considerably restricted the jurisdiction of the court. We first summarize our data collection and coding strategies, and then summarize the results.

\section{A. Data Collection, Case Coding, and Hypotheses}

In the prior Part we addressed the history of the three-judge district court through statutes passed by Congress, their application and interpretation by federal courts, and by reviewing how some litigants pursued certain types of litigation through those courts. In this Part, we focus mainly on decisions of those courts. Our starting point is the data found in Tables 1 and 2, which provide the landscape of the large number of such cases in U.S. District Courts and on direct appeal to the Supreme Court. But that data tells us little about individual cases. There is empirical literature on decision-making by federal district judges, and by the Supreme Court, but as far as we know, relatively

94. David W. Romero \& Francine Sanders Romero, Precedent, Parity, and Racial Discrimination: A Federal/State Comparison of the Impact of Brown v. Board of Education, 37 LAW \& SoC'Y REv. 809, 821 (2003).

95. Calvin Montgomery Miller, The Impact of the Abolition of Three-Judge District Courts on Minority Litigants' Access to the Federal Courts 1 (1977) (Ph.D. dissertation, Lehigh University) (on file with the author). Among other things, Miller found that in 320 decisions, plaintiffs prevailed in $45 \%$ at the trial level and in $77 \%$ of those appealed to the Supreme Court. Id. at 103. These figures compared favorably to other studies of single district judges in race relation cases in the South at about the same time. Id. at 103-04. All of these studies are further summarized and discussed in Solimine, Congress, Ex Parte Young, supra note 23, at 129-31. 
little of it focuses on three-judge district court decisions or direct appeals from those cases. ${ }^{96}$

To fill this gap, we created our own dataset of those cases. As we have already stated, our focus was on decisions in district courts and direct appeals of those decisions to the Supreme Court from 1954 to 1976. The years are respectively based on the advent of the Civil Rights era, insofar as it reflected in decisions by federal courts, and when Congress considerably restricted the jurisdiction of the court. While during that same time frame some constitutional challenges to federal statutes had to be adjudicated before a three-judge district court, our focus for this study is challenges to state laws. As far as we are aware, there is no available list of or database focusing on three-judge district court decisions concerning such challenges. To create such a database, we conducted searches on Westlaw of officially published opinions ${ }^{97}$ of such courts, in constitutional challenges to state laws, handed down between January 1, 1954, and December $1,1976 .{ }^{98}$ The searches yielded 885 decisions.

96. On district court decisions, see, e.g., C.K. Rowland \& Robert A. Carp, Politics \& Judgement in Federal District Courts 18 (1996), which analyzes and reports data on over 40,000 decisions, published in the Federal Supplement, by individual district judges over a 40 -year period. There is a huge literature on Supreme Court decisions, much of it based on The Supreme Court Database, supra note 80 , but to our knowledge it makes only passing reference, if at all, to direct appeals from three-judge district courts.

97. By this we mean decisions published in the Federal Supplement (F. Supp.) or Federal Rules Decisions (F.R.D.). For the time period in question, and before and after, there are relevant decisions that are not published in those places, but nonetheless available on Westlaw or in other ways. But we are confident that most three-judge district court decisions, involving the non-trivial issue of a constitutional challenge to a state law, would be more likely to be published, especially (though not only) if the decision was directly appealed to the Supreme Court. Limiting the database to officially published decisions should capture a very large fraction of cases that we seek to study. For further discussion of the official publication of decisions of district courts, see RowLAND \& CARP, supra note 96, at 1821; Christina L. Boyd, Pauline T. Kim \& Margo Schlanger, Mapping the Iceberg: The Impact of Data Sources on the Study of District Courts, 17 J. Empirical Legal Stud. 466, 467-69 (2020); Aaron-Andrew P. Bruhl, Statutory Interpretation and the Rest of the Iceberg: Divergences Between the Lower Federal Courts and the Supreme Court, 68 Duke L.J. 1, 2526, 34-35 (2018); Solimine, Voting Rights Litigation, supra note 36, at 114 n.204. Likewise, our database is limited to those Supreme Court decisions that were the result of direct appeals of officially published three-judge district court decisions. We anticipate that relatively few non-officially published three-judge district court decisions will be subject to full explanatory decisions upon direct review. See $i d$.

98. Congress acted in August of 1976, see supra note 59 and accompanying text, but the legislation did not apply retroactively, see supra note 78 and accompanying text, so three-judge district court cases being litigated at 
With the aid of research assistants, we coded each decision on a number of variables to test, among other things, what for convenience we label the Strange Career hypothesis. ${ }^{99}$ The variables included:

- the location (i.e., which U.S District Court and in what Circuit) of the court that issued the decision;

- the composition of the panel (two district judges and one circuit judge, or vice-versa);

- whether there was a concurring or dissenting opinion; the nature of the lead plaintiffs (i.e., an individual, interest group, a business, or something else);

- the subject matter of the case, broadly described;

- whether plaintiff prevailed, by obtaining an injunction or other relief against the state law (or whether the case was resolved on other grounds, without a ruling on the request for an injunction);

- no matter the ruling, whether there was a direct appeal to the Supreme Court and, if so, what was the result of that appeal (i.e., whether there was a summary affirmance or reversal, or a decision with an explanatory opinion after briefing and (typically) oral argument).

In addition, several of the variables allow us to test, or at least shed light on, several hypotheses, which can be considered sub-issues of the general Strange Career hypothesis. One is whether such courts indeed were on the whole relatively plaintiff-friendly during some or all of the Civil Rights Era. This might be measured in different ways, but the primary variable we consider is whether or not the court granted, in whole or in part, the injunctive or other relief sought by the plaintiff. The statute, in all its variations, only requires the convening of the specialized court when an injunction is sought against the state law. ${ }^{100}$

the time continued to be so. Some of the cases were only resolved in 1977 and 1978, but we concluded that closing the database on Dec.1, 1976 best captured the era that interests us. The searches and other aspects of the creation of the database, and the coding of decisions, are described in greater detail in the Methodological Appendix.

99. In determining which variables to code, we found particularly helpful the work of C.K. Rowland and Robert Carp in their analogous coding of decisions by individual district judges dealing with civil-rights and liberties issues. See Rowland \& CARP, supra note 96, at 22-23. For further discussion of, and best practices for, the coding of court decisions, see generally Mark A. Hall \& Ronald F. Wright, Systematic Content Analysis of Judicial Opinions, 96 CAL. L. REV. 63 (2008).

100. 28 U.S.C. $\S \S 2281,2284$ (1970). Section 2281 was repealed by Act of Aug. 12, 1976, Pub. L. 94-381, § 1, 90 Stat. 1119. The Supreme Court, and lower courts, have not been clear on whether the seeking of a declaratory judgment alone will require the convening of the court. A declaratory judgment is not mentioned in the statute, but some decisions held that the statute is triggered if the granting of such relief would be tantamount 
That (near) binary choice does not have the complications of classifying other types of relief, such as different types or amounts of damages. ${ }^{101}$

Another hypothesis is premised on the assumption that the threejudge district court was often said to be especially important, and plaintiff-friendly, in civil-rights litigation in the South (however one defines that region). So we can examine the number and results of decisions from that region, as compared to other parts of the country. Corollaries of that assumption could be that a disproportionately greater number of such cases were brought in the South, and similarly that there were more direct appeals to the Supreme Court from the South. At least during the time in question, the Supreme Court appeared to have spent considerable time deciding cases from that region involving civil rights and liberties. ${ }^{102}$

There has been some suggestion that three-judge district court decisions are appealed at a higher rate, via direct appeals to the Supreme Court, than appeals from other district court decisions to the Courts of

to the granting of injunctive relief or if the issues regarding the two types of relief were the same, e.g., Roe v. Wade, 410 U.S. 113, 123 (1973), and the Court never definitively resolved the issue. Currie, supra note 9 , at 13-20 (discussing the cases up to 1964). Sometimes plaintiffs requested both an injunction and a declaratory judgment, and sometimes a court would deny or not rule upon the former while granting the latter, on the basis that the former was unnecessary since the court expected the state to conform to the holding. See, e.g., Henley v. Wise, 303 F. Supp. 62, 7172 (N.D. Ind. 1969) (three-judge court); Melton v. City of Atlanta, 324 F. Supp. 315, 320 (N.D. Ga. 1971) (per curiam) (three-judge court); Roe v. Wade, 314 F. Supp. 1217, 1224 (N.D. Tex. 1970). In other cases the court would decline to issue an injunction but grant a declaratory judgment in order to let the legislature act. See, e.g., Yancey v. Faubus, 238 F. Supp. 290, 300-01 (E.D. Ark. 1965) (three-judge court); Garza v. Smith, 320 F. Supp. 131, 139-40 (W.D. Tex. 1970) (three-judge court). See generally Samuel L. Bray, The Myth of the Mild Declaratory Judgment, 63 Duke L.J. 1091 (2014) (discussing the similarities and differences between the two types of relief). For coding purposes we treated a grant of a declaratory judgment as the equivalent of the grant of an injunction.

101. The breadth of our coverage of cases, and our coding, permits us to examine district-court cases, and those decided on direct appeal by the Supreme Court, where the state laws were either upheld or declared unconstitutional. Cf. Matthew E.K. Hall \& Ryan C. Black, Keeping the Outliers in Line? Judicial Review of State Laws by the U.S. Supreme Court, 94 Soc. ScI. Q. 395, 399-400 (2013) (study of all state laws passed between 1960 and 2004, and the instances they were invalidated by the Supreme Court; did not study cases where laws were upheld); Lindquist \& Corley, supra note 2, at 157-60 (examining Supreme Court decisions during Burger and Rehnquist Courts to uphold or invalidate state laws, but with no direct mention or analysis of appeals from three-judge district courts).

102. Lucas A. Powe, Jr., The Warren Court and American Politics 489-92 (2000); Karen O'Connor, The Supreme Court and the South, 63 J. Pol. 701, 703 (2001). 
Appeals. Some sources suggest that the rate of appeal of the former was, in various years, often up to about $40 \%$, which is about double the rate of appeal for cases before single district judges. ${ }^{103}$ One of the reasons for the establishment of the three-judge court was that the legal community, and presumably the larger public, would give a decision by three judges, rather than just one, greater respect and acceptance. If true, one might expect that deference to be reflected by a lower rate of appeal to the Supreme Court. ${ }^{104}$ In possible contrast, one might expect state government officials, because of greater resources and political pressures, to appeal plaintiff victories in these cases at a higher rate than other plaintiffs who lose before individual judges. That is, state governments might be under political pressure to take all steps to defend state laws, especially when the Supreme Court must hear the appeal, as compared to the uncertainty of certiorari petitions. ${ }^{105}$

Coding the rate of direct appeal to, and the disposition of those appeals by, the Supreme Court, unpacks further aspects of the unique relationship between three-judge district courts and the Court. The vast majority of civil and criminal cases in the federal courts are governed by the same, familiar institutional arrangements. A case will be resolved at the trial level, with one judge in charge, and the losing party will have the option of pursuing one appeal as of right to the appropriate circuit court of appeals. The losing party there may request a discretionary review by the Supreme Court via a writ of certiorari. Relatedly, differences between trial and appellate judges are widely acknowledged. District judges work alone and decide a wide variety of disputes and motions, sometimes of necessity rapidly, mostly relating to the application of more-or-less well-settled law to factual disputes, and then preside over trials if the case is not settled or resolved by a pretrial motion. In contrast, circuit judges collaboratively decide appeals on three-judge panels and review trial court dispositions - usually with few time constraints - with a preset factual record, under de novo review for legal issues, and various standards of deferential review for factual determinations. ${ }^{106}$

103. See Solimine, Voting Rights Litigation, supra note 36, at 99 (discussing sources).

104. Id.

105. See generally Christina L. Boyd, Litigant Status and Trial Court Appeal Mobilization, 37 LAW \& POL'Y 294 (2015) (study of appeals in federal district-court civil cases between 2000 and 2004, exploring motivations of different types of appellants).

106. For a useful comparison of the work of district and appellate judges, with citations to the ample literature discussing those differences, see Pauline T. Kim, Margo Schlanger, Christina L. Boyd \& Andrew D. Martin, How Should We Study District Judge Decision-Making?, 29 WASH. U. J.L. \& POL'Y 83, 86-94 (2009). 
Contrast these familiar patterns with the convening of and decisionmaking by three-judge district courts. These courts are often described as an awkward fit for the judges and litigants involved, and it is not hard to see why. Judges who normally serve on different levels must sit together at the trial level and engage in joint decisions to decide legal issues and create a factual record. Indeed, the circuit judges would normally sit in review of their district-judge temporary co-panelists. This amalgam of different skillsets and relationships might result in creativity and more thoughtful decisions. On the other hand, it might result in some frustration with the judging process, such as arguably undue deference by the district judges to the circuit judge. For example, some studies have shown that the circuit judge will author a disproportionate number of opinions issued by three-judge district courts, perhaps demonstrating deference by the district judges on the panel..$^{107}$ Lawyers used to litigating the vast majority of civil and criminal cases before one judge might find it odd to litigate a case before a tribunal that has elements of both a trial and appellate court. ${ }^{108}$

The awkward fit continues when considering the relationship of the three-judge district court with the Supreme Court. Normally, district judges know their decisions can be subject to at least one appeal as of right by a three-judge panel on the circuit. Appeals judges know their decisions can be subject to en banc review by the entire circuit, or by the Supreme Court through a writ of certiorari. In each instance, though, the judges also know that the overturning of their solo or collective decisions will be rare: most cases aren't appealed at all; those that are appealed are affirmed at a high rate; en banc review is rare; and the vast majority of writs of certiorari are denied. ${ }^{109}$

107. For discussion of the issues raised in this paragraph, see Maxwell Mak \& Andrew H. Sidman, Separate Opinion Writing Under Mandatory Appellate Jurisdiction: Three-Judge District Panels and the Voting Rights Act, 17 J. Empirical Legal Stud. 116, 124 (2020); Solimine, Voting Rights Litigation, supra note 36, at 116-18; Thomas G. Walker, Behavioral Tendencies in the Three-Judge District Court, 17 Midwest J. Pol. ScI. 407, 408-11 (1973). That said, there is a long-standing practice of district judges sitting by designation on the courts of appeals. See StePhen L. Wasby, Borrowed Judges: Visitors in the U.S. Court of Appeals 1-2, 7-9, 229-30 (2018).

108. One lawyer during the period we examined referred "to the tendency on the part of three-judge federal courts to browbeat you into a stipulated record or cross motions for summary judgment, because they do not have the time to spend on the case before them." Alfred L. Scanlan, The Trial and Appeal of Constitutional Issues, 20 CATH. LAw. 386, 389-90 (1974).

109. Most circuit judges, studies show, typically do not act strategically to the possible threat of reversal by the Supreme Court, in part given the low possibility of grants of certiorari. See Virginia A. Hettinger, Stefanie A. Lindquist \& Wendy L. Martinek, Judging on a Collegial Court: Influences on Federal Appellate Decision Making 35-36, 114-15 
Now contrast that with the Court's process of disposing of direct appeals from three-judge district courts, which is subject to its own complications. The governing statutes arguably require the Court to hear and decide all direct appeals, in the sense of giving some reasoned opinion explaining the result. ${ }^{110}$ But the Court has never done this, and instead has almost always treated the request for direct review as the near functional equivalent of a petition for a writ of certiorari. It accomplishes this by reserving the right to summarily affirm or reverse the appeal; if that step is not taken, then "probable jurisdiction is noted," and the appeal is typically set for full briefing and oral argument, with an explanatory decision to follow. ${ }^{111}$ True, this is not identical to the certiorari process, for unlike a denial of certiorari, the Court has held that summary dispositions are technically "on the merits" for purposes of precedent. ${ }^{112}$ But the two types of appellate review have come to be similar.

How this affects judges sitting on three-judge district courts is unclear, regarding the possibility of review of their decisions on that court. Given the similarities just described, the effects (if any) are probably similar to the certiorari regime. ${ }^{113}$ And we are aware of only fairly episodic empirical studies of the rate of direct appeals and their disposition by the Court. ${ }^{114}$ We could thus expect these narrow studies to be reflected in a broader compilation of data of our study.

(2006); Jennifer Barnes Bowie \& Donald R. Songer, Assessing the Applicability of Strategic Theory to Explain Decision Making on the Courts of Appeals, 62 PoL. Rsch. Q. 393, 394-96 (2009). This is not to say that these lower court judges act as if review of their decisions doesn't exist. Judges will typically take into account, explicitly or implicitly, the likelihood of reversal by a higher court, and while precise measurement is impossible, it appears higher court precedent is largely followed by lower courts even with low possibility on average of review and reversals. See David E. Klein \& Robert J. Hume, Fear of Reversal as an Explanation of Lower Court Compliance, 37 LAw \& Soc'y REv. 579, 582-84 (2003); Kirk A. Randazzo, Strategic Anticipation and the Hierarchy of Justice in U.S. District Courts, 36 Am. Pol. Rsch. 669, 685 (2008).

110. Douglas \& Solimine, supra note 64 , at $424-25$.

111. H.W. Perry, Jr., Deciding to Decide: Agenda Setting in the United States Supreme Court 31, 105 (1991); Stephen M. Shapiro, Kenneth S. Geller, Timothy S. Bishop, Edward A. Hartnett \& Dan Himmelfarb, Supreme Court Practice $\S 5.16$, at 5-55 to 5-56, $\S 5.19$, at 5-59, § 5.21, at 5-61 (11th ed. 2019); Douglas \& Solimine, supra note 64 , at 419,424 .

112. Douglas \& Solimine, supra note 64 , at $423-24$.

113. Solimine, Voting Rights Litigation, supra note 36, at 108-09.

114. See supra notes 50, 103 and accompanying text. Cf. Mak \& Sidman, supra note 107 (study of three-judge district decisions in VRA cases from 1965 to 2016, examining effect of availability of direct appeals on judicial decision-making, though not examining any direct appeals themselves). 


\section{B. Results of Study}

1. Overall Number and Types of Cases

Table 1 provides information on the number and subject matter of all three-judge district cases during the 1954-1976 time period. Table 3 provides parallel information on a somewhat smaller data set, focusing on constitutional challenges to state laws. ${ }^{115}$ While we have discussed the racial desegregation cases from the 1950s in this Article, what is especially notable in both of those tables is the large increase in threejudge court cases after the 1950s. In particular, there were several scores of decisions each year from the late 1960s to the mid-1970s.

What accounted for this noticeable increase in decisions? Part of the answer is likely the straightforward reason that there were increasingly more cases overall in federal court, more federal judges, and more lawyers. The number of cases and judges in federal district courts rose by about $50 \%$ over the time period in question. ${ }^{116}$ Likewise, civil-rights litigation continued to rise in this period. ${ }^{117} \mathrm{~A}$ consequence of this increased litigation was no doubt an increase in the types of actions that required the convening of three-judge district courts, and a related increase in direct appeals of those cases to the Supreme Court. ${ }^{118}$

The increase in three-judge-court cases in the 1960s and 1970s was surely also influenced by the number and types of lawyers and lawyering during this period. ${ }^{119}$ We have already observed that much of the desegregation litigation in the 1950s was brought by the NAACP. That organization (and its related but separate group, the NAACP Legal Defense Fund) continued to litigate race-related and other civil rights

115. In this Table and the remaining ones, we present counts and frequencies, but do not engage in multivariate or other statistical analysis. Our quantitative descriptive analysis is particularly appropriate given that we are using a complete data set, not a sample of a larger set. See Hall \& Wright, supra note 99, at 117-18. We leave further statistical analysis for another day.

116. David S. Clark, Adjudication to Administration: A Statistical Analysis of Federal District Court Courts in the Twentieth Century, 55 S. CAL. L. REV. 65, 69-71 tbl.1 (1981) (district court judges increased from 238 in 1954 to 375 in 1976 ); $i d$. at $86-88$ tbl. 2 (cases terminated rose from 100,517 in 1954 to 153,850 in 1976).

117. Sean Farhang, The Litigation State: Public Regulation and Private Lawsuits in The U.S. 5 (2010) (discussing "steep rise in private enforcement litigation" in the federal courts in the late 1960s and early 1970s, based on 42 U.S.C. $\S 1983$ and other statutes); Hellman, supra note 82, at 40 n.164; Carl Tobias, Public Law Litigation and the Federal Rules of Civil Procedure, 74 Cornell L. Rev. 270, 284-85 (1989).

118. Hellman, supra note 82 , at 60 n.231.

119. In what follows, we acknowledge relying on secondary sources on civilrights litigation in general. Due to resource limitations, we did not code or otherwise seek information about the lawyers appearing in the decisions in our database. 
cases in the following decades. ${ }^{120}$ Other interest groups, notably the American Civil Liberties Union, also brought many suits challenging state practices on constitutional grounds in these decades, and they were joined in that endeavor by an increasingly broad array of public interest groups, legal aid societies, and law firms. ${ }^{121}$ Legal practice was changing too; attorneys were increasingly specializing and working in law firms, as compared to the solo-practice model that characterized much of American legal history. ${ }^{122}$

To be sure, this formidable array of litigators did not necessarily act in a highly coordinated way. There is no evidence of a specialized bar that focused on three-judge district court cases as such. As with other legal work, these organizations and lawyers did not have unlimited time or resources, and a variety of factors led to any given case being filed, or not. ${ }^{123}$ And as we pointed out earlier, the relevant statutes, while no models of clarity in text or in application, required that a three-judge district court be convened when an injunction was sought against a state law due to its unconstitutionality, whether specifically sought by plaintiffs' lawyers or not. ${ }^{124}$

Another factor, interrelated with lawyer activity, driving the increase in civil-rights cases in general and, concomitantly, three-judge district court cases in particular, were changes in procedural and substantive law that facilitated the bringing of such cases. Namely, in the 1960s the Supreme Court and lower federal courts made it easier for

120. See generally Peter Charles Hoffer, The Search For Justice: Lawyers in the Civil Rights Revolution 1950-1975 (2019); Timothy J. Minchin, Making Best Use of the New Laws: The NAACP and the Fight for Civil Rights in the South, 1965-1975, 74 J.S. HiST. 669 (2008).

121. Risa Goluboff, Vagrant Nation: Police Power, Constitutional Change, And the Making of the 1960s, at 129-30 (2016); James T. Patterson, Grand Expectations: The United States, 1945-1974, at 640-41 (1996); Robert W. Gordon, Lawyers, the Legal Profession \& Access to Justice in the United States: A Brief History, 148 DæDalus 177, 183 (2019); Tobias, supra note 117, at 276, 279-85.

122. Stephen C. Yeazell, Brown, the Civil Rights Movement, and the Silent Litigation Revolution, 57 VAND. L. REV. 1975, 1991-92 (2004).

123. For an extensive study of the resources available to and constraints on civil-rights groups and lawyers in this era, and of the impact on litigation strategy, see Stephen L. Wasby, Race Relations in an Age of Complexity 78-82, 194-95, 209-15 (1995).

124. That said, there is some evidence in three-judge court litigation as a whole of lawyers engaging in some forum- or judge-shopping, as can be true in ordinary litigation. If there was more than one District Court in a state, depending on the circumstances of the case, plaintiffs might have some options in where suit could be brought. (Even states with only one District can have different cities where different judges sit.) Depending on who the Chief Judge of the circuit was, plaintiffs might be able to predict that favorable judges, as they saw it, would be appointed to the three-judge court. Solimine, Voting Rights Litigation, supra note 36, at 101-02. 
plaintiffs to bring actions under 42 U.S.C. $\S 1983$; relaxed standing requirements for plaintiffs; and amendments to Federal Rule of Civil Procedure 23 in 1966 to make it easier for class actions to be certified. ${ }^{125}$ These and similar changes operated as a feedback loop, encouraging attorneys to bring new cases, some of which ended up on the Supreme Court's docket. ${ }^{126}$ For example, the Supreme Court initiated the Reapportionment Revolution in 1962 in Baker $v$. Carr, itself originating as a three-judge district-court case. ${ }^{127}$ That decision led to a stream of cases challenging legislative districting by States, which required many three-judge courts to be convened. ${ }^{128}$

As we have mentioned, portions of Table 1 divide three-judge district court cases between civil rights, reapportionment, and others. We sought an even finer-grained analysis in our study. We coded the decisions on whether they primarily raised claims under the Fourteenth Amendment (other than race), the free expression clauses of the First Amendment (speech, press, assembly), race, religion, voting (including reapportionment), and economic regulation. The results for the entire period are found in Table 4. Leading the types of case are the Fourteenth Amendment (51\%), voting (18\%), free expression (14\%), race $(7 \%)$, and economic regulation (5\%). These counts are not particularly surprising, since we would expect constitutional ${ }^{129}$ challenges during the Warren, and the first half of the Burger, Courts to be dominated by Equal Protection and Due Process cases. ${ }^{130}$ Also telling is that relatively

125. On $\S 1983$ litigation, see Hugh Davis Graham, Legacies of the 1960s: The American "Rights Revolution" in an Era of Divided Governance, 10 J. POL'y Hist. 267, 271 \& n.13 (1998), for a discussion of Monroe v. Pape, 365 U.S. 167 (1961), which held that conduct challenged in a $§ 1983$ action did not have to be based on a state statute. On relaxed standing in this period and its relation to civil-rights litigation, see Seth Davis, The New Public Standing, 71 Stan. L. Rev. 1229, 1253 (2019). On the amendment to Rule 23 and its effect on public law litigation, see Tobias, supra note 117, at 280; see also Zambrano, supra note 51, at 2121.

126. Hellman, supra note 82, at 56-58. See generally VANEssa BAIRD, ANswering the Call of the Court: How Justices and Litigants Set the Supreme CourT's AGENDA (2007) (discussing how litigants that monitor the Court can affect the law by bringing certain cases before the courts).

127. See supra note 60 and accompanying text.

128. Michael E. Solimine, The Causes and Consequences of the Reapportionment Revolution, 1 EleCtion L.J. 579, 582 (2002) (book review).

129. We coded only constitutional issues, even though three-judge district courts may have also considered and decided pendent claims that state laws also violated federal statutes. See Solimine, Voting Rights Litigation, supra note 36, at 96. See also Thomas v. Reeves, 961 F.3d 800, 801-08 (5th Cir. 2020) (en banc) (Costa, J., concurring) (holding that a three-judge court cannot be convened to hear purely statutory challenges to apportionment).

130. See Herbert M. Kritzer, Polarized Justice? Changing Patterns of DecisionMaking in the Federal Courts, 28 KAN. J.L. \& PUB. POL'y 309, 365-66 
few cases involved challenges to economic regulations, meaning that the vast majority of the cases involved what we may label traditional civil rights and liberties actions, brought by individual plaintiffs. ${ }^{131}$

2. National and Regional Trends and Differences: Frequency and Results of Cases

We have already noted that during the period of review, the Supreme Court, especially during the Warren Court, was vigilant about reviewing civil and criminal cases from the South (however one defines that word in this context), given the history of Jim Crow and race relations centered in that region. ${ }^{132}$ This alone would not necessarily mean we would expect more three-judge district court litigation in that region. But together with the anecdotal accounts of such litigation in the South in the 1950s, ${ }^{133}$ and the considerable activity of the NAACP and other civil rights groups in the region, it is suggestive of that result.

The suggestion is supported by the data we report in Table 5 . It shows that the largest proportion $(26 \%)$ of such decisions are from district courts in the Fifth Circuit. ${ }^{134}$ (For convenience we'll keep referring

(2019) (reporting data showing decreased attention to economics and regulation, and increased attention to civil rights and liberties, in districtcourt decisions from 1940 to 2000). For detailed analysis of the types of cases litigated before three-judge district courts, see Singley, supra note 56 , at 373-74, analyzing data reported in Congressional hearings on the types of cases in fiscal years 1972 and 1973, including abortion, public aid to religious schools, penal codes, residency requirements, obscenity, voting, and welfare, among other things; Commentary, Why Three-Judge District Courts?, 25 Ala. L. REv. 371, 381-82 (1973), presenting a sample of eighty-seven cases decided in 1971 which included abortion, welfare, voting, First Amendment, and prejudgment attachment cases.

131. In data not reported in a table, $81 \%$ of the lead plaintiffs were individuals, $10 \%$ were businesses, and $5 \%$ were interest groups. Data on file with Solimine.

132. See supra note 102 and accompanying text. See also Robert Jerome Glennon, The Jurisdictional Legacy of the Civil Rights Movement, 61 TEnN. L. REV. 869, 875-76 (1994) (discussing vestiges of Jim Crow and discrimination in voting rights and the criminal-justice system in the South in the post-WWII era); Lindquist \& Corley, supra note 2, at 170 (finding that the Burger and Rehnquist Courts were more likely to invalidate statutes from Southern states as compared to other regions). See generally Amanda Clare Bryan \& Ryan J. Owens, How Supreme Court Justices Supervise Ideologically Distant States, 45 Am. PoL. Rsch. 435 (2017).

133. See supra notes $82-88$ and accompanying text.

134. Here we refer to the old Fifth Circuit, which was much larger than the present Fifth Circuit, which consists of Louisiana, Mississippi, and Texas. See Arthur D. Hellman, Deciding Who Decides: Understanding the Realities of Judicial Reform, 15 LAW \& Soc. INQUIRY 343, 345-47 (1990). Congress in 1980 split off Alabama, Florida and Georgia into a new Eleventh Circuit, since the growing population and the large number of cases had made administration of the old circuit unwieldy. See $i d$. Echoing the legislative 
to the circuits, even though we are only focusing on three-judge district courts convened within each circuit. ${ }^{135}$ ) It grows almost another $10 \%$ if we add decisions from the Fourth Circuit, which includes North and South Carolina and Virginia. The percentages from all of the other regional circuits trail behind. That said, two somewhat surprising results are the relatively few decisions from the Ninth Circuit (7.7\%) and the relatively many decisions (15\%) from the Second Circuit. The former is likely due to the circuit not resembling, one or two generations ago, the large, populous circuit of today. For the latter, one might not expect the relatively liberal states ${ }^{136}$ of New York and Connecticut to be a focus of civil rights litigation, and resultant three-judge district-court decisions. But those states have, surprisingly or not, generated such cases concerning abortion, voting, reapportionment, and welfare. ${ }^{137}$ No doubt the historic concentration of the legal community, and the stock of statutes that could be targeted in litigation in those older states, played a large role.

debate a few years earlier over the near total demise of the three-judge district court, some civil-rights groups opposed the change, in part because they felt the old Fifth Circuit was generally supportive of their interests and were uncertain of their prospects if the circuit was split. See id. See generally Deborah J. Barrow \& Thomas G. Walker, A Court Divided: The Fifth Circuit Court of Appeals and the Politics of Judicial ReForm 194-96, 239-41 (1988).

135. Three-judge district courts had and have a fraught hierarchical relationship with a circuit; they are both within and apart from it. See Douglas \& Solimine, supra note 64 , at 447-448. The court literally sits within a circuit, and the judges sitting on it are appointed from the circuit (though curiously the statute does not require that the two additional judges (i.e., in addition to the district judge to whom the case was originally assigned) be from the circuit). See id. at 416, 418, 422. But the court's decision is only appealable to the Supreme Court, not the circuit. See id. at 416, 422. This has led to a split in the cases regarding whether the court is bound by circuit precedent, as compared to only Supreme Court precedent; the Court has never directly addressed the issue. See $i d$. at 445-54 (discussing hierarchical issues and concluding that three-judge district courts may follow circuit precedent but are not required to). But see Morley, supra note 22, at 745-66 (arguing that such courts must follow circuit precedent).

136. See Devin Caughey \& Christopher Warshaw, The Dynamics of State Policy Liberalism, 1936-2014, 60 AM. J. POL. SCI. 899, 900 (2016) (reporting a study of legislation passed by states from 1936 to 2014, showing that "the most conservative states are in the South, whereas California, New York, Massachusetts, and New Jersey are always among the most liberal").

137. E.g., Abele v. Markle, 342 F. Supp. 800 (D. Conn. 1972) (three-judge court) (abortion law); Kelly v. Wyman, 294 F. Supp. 893 (S.D.N.Y. 1968) (three-judge court) (welfare assistance), aff'd sub nom. Goldberg v. Kelly, 397 U.S. 254 (1970); Kramer v. Union Free Sch. Dist. No. 15, 282 F. Supp. 70 (E.D.N.Y. 1968) (three-judge court) (voting restrictions), rev'd, 395 U.S. 621 (1969); Wells v. Rockefeller, 281 F. Supp. 821 (S.D.N.Y. 1968) (three-judge court) (reapportionment), rev'd, 394 U.S. 542 (1969). 
We can now consider the overall results of the cases, focusing on whether the court granted the injunctive relief sought by plaintiffs. The data, broken down by circuit, is found in Table 5. Over the twentythree years we study, the courts granted injunctions (or other relief), in whole or in part, in some $51 \%$ of the cases. That figure is fairly consistent among most of the circuits. It is at $42 \%$ and $52 \%$, respectively, in the Fourth and Fifth Circuits, which encompassed most the states that were the locus of many of the notable civil rights cases in the era under study. The percentages are fairly stable over time as well, as the breakdown in Table 6 indicates. From 1961 through 1974, which we might consider the height of the Civil Rights era, courts granted $52 \%$ of injunctions sought.

Overall, then, we can conclude that there is some support for the Strange Career hypothesis. Originally it was premised on largely anecdotal accounts of well-known civil rights and liberties cases. ${ }^{138}$ Later studies expanded it to larger numbers of decisions of three-judge district court decisions, in the decade or two after the 1950s. ${ }^{139}$ Our study more comprehensively studies the entire 1954 through 1976 period, and largely replicates those earlier studies. Still, we are painting with a broad brush, and it must be asked for all of these studies, "as compared to what?" Perhaps many federal district and circuit judges in ordinary litigation were holding for civil rights plaintiffs at relatively high rates during some or all of this era, which would dilute the significance of the data we find for three-judge district courts. Of course, we can never know for sure; the actual cases litigated before three-judge district courts cannot be relitigated in the ordinary process to determine if different outcomes would have resulted.

What we can do is to compare our results to those studies of individual district-judge or appellate-court litigation in civil-rights and civil-liberties cases at comparable times which are relatively similar to those litigated before three-judge district courts. Recall that this is what was done in several earlier studies. Those studies found that, to varying degrees, three-judge district courts held for plaintiffs at higher rates than individual district judges. ${ }^{140}$ To augment those studies, we can compare our more comprehensive data to that published by Robert Carp and his associates subsequent to the studies we just mentioned. They studied over 45,000 decisions officially published (in the Federal Supplement), by over 1,500 district judges from 1933 through $1987 .{ }^{141}$

138. See supra notes $82-88$ and accompanying text.

139. See supra notes 93-95 and accompanying text.

140. See supra notes 93-95 and accompanying text.

141. Rowland \& CARP, supra note 96, at 17-18. They did not study threejudge district courts. Id. at 18. Carp and other co-authors have published follow-up studies and most recently have extended the cited study to cover over 90,000 officially published decisions handed down between 1927 and 
Their data is broken down by subject matter, time, and region that allows some comparisons to our data. For the 1954-1968 and 1969-77 periods, closely matching the era we study, they report that district judges in civil-rights and -liberty cases in the South issued "liberal" decisions (i.e., upholding the asserted right) $42 \%$ and $45 \%$ of the time, respectively. ${ }^{142}$ The comparable figures for other regions are the North $(39 \%, 53 \%)$, East $(39 \%, 51 \%)$, and West $(41 \%, 49 \%) .{ }^{143}$ Carp and his associates conclude that district judges in the North during this period were generally more supportive of civil rights and liberties than their colleagues in the South. ${ }^{144}$ So too, comparing his data with ours, we can conclude that there is some support for the notion that three-judge district courts were somewhat more supportive of civil rights plaintiffs than individual district judges. We come to this conclusion with the modifiers just noted; the differences are not of a quantum nature and, while modest, are noticeable. ${ }^{145}$

2008. See Marc A. Sennewald, Kenneth L. Manning \& Robert A. Carp, The Polarization of the Judiciary, 23 PARTY PoL. 657, 659 (2017). Carp and his associates, like many other political scientists, have also studied the ideological influences on federal judicial behavior by using the political party of the appointing President, or other measures, as a proxy for ideology. See Rowland \& CARP, supra note 96, at 12-13. See also Adam Bonica \& Maya Sen, Estimating Judicial Ideology, 35 J. Econ. Persps. 97, 9799 (2021); Ryan Hübert \& Ryan Copus, Political Appointments and Outcomes in Federal District Courts, 84 J. PoL. 908, 910 (2022). We did not specifically code that measure, and we leave it for another day.

142. Rowland \& CARP, supra note 96 , at 61 .

143. Id. Different studies place varying states in these regional categories. For example, we typically use the (old) Fifth Circuit as a proxy for the South, and sometimes fold in the Fourth Circuit as well. In contrast, for the South, Rowland and Carp use states from the old Fifth Circuit, the Fourth Circuit, as well as Arkansas, Kentucky, Missouri, and Tennessee. Id. at 60 \& 186 n.9. These differences should be kept in mind but don't severely undermine our use of the Rowland and Carp study for comparative purposes.

144. Rowland \& CARP, supra note 96, at 65. Cf. Kritzer, supra note 130, at 363-64 (suggesting that conservatism of federal judges in the South in this period could be overstated).

145. Since a three-judge district court consisted of at least one circuit judge, it would also be appropriate to examine their voting patterns as well. Studies have shown that "southern judges [on the Fourth and Fifth Circuits] of both parties were substantially more conservative than northern judges in their voting patterns in civil rights cases before 1969." Donald R. Songer \& Sue Davis, The Impact of Party and Region on Voting Decisions in the United States Courts of Appeals, 1955-1986, 69 W. PoL. Q. 317, 320, 330 (1990) (reporting a study based on a sample of circuit decisions from 195558 and 1965-68). These studies tend to support the notion that three-judge district courts within the southern circuits were on the whole more supportive of civil-rights plaintiffs than the appeals judges on those circuits. 
3. Direct Appeals to the Supreme Court: Frequency and Disposition

We have observed that prior episodic evidence suggests both that there would be a relatively high rate of appeal from three-judge district court decisions to the Supreme Court, and that the Court would dispose of a large fraction of these appeals by summary disposition, rather than by oral argument followed by an explanatory opinion (akin to a grant of certiorari). ${ }^{146}$ Our study has largely replicated these results, and adds further nuances. ${ }^{147}$

As Table 7 indicates, a direct appeal was filed in $48 \%$ of the decisions we coded, over double the usual rate of appeal from district court decisions. Table 7 is also broken down by circuit. It shows some deviations: the rate ranged from a high of $63 \%$ in the Second Circuit, to a low of $35 \%$ in the Third Circuit. But most of the circuits are fairly close to $50 \% .{ }^{148}$ This data tends to support the notion that three-judge district cases, as envisioned by the 61st Congress, considered important issues - enough so that the losing litigants were frequently willing to press the case to the Supreme Court. On the other hand, it seems to show relatively little final acceptance of the court's decisions (to the extent that can be measured by the rate of appeal), or that governmental officials and entities would be more likely to appeal as compared to the typical plaintiff.

We also considered the effect of the decision-making by the threejudge panel on the rate of appeal. Only relatively modest numbers of

146. See supra notes $48,102-05$ and accompanying text.

147. One nuance is that when three-judge district courts issued a declaratory judgment rather than an injunction, see supra note 100, a direct appeal did not generally lie to the Supreme Court under 28 U.S.C. $\S 1253$. Rather, an appeal could only be made to a court of appeals, as in any other case. See, e.g., Garza v. Smith, 320 F. Supp. 131 (W.D. Tex. 1970) (three-judge court), remanded, 450 F.2d 790 (5th Cir. 1971); Wolfe v. Shroering, 388 F. Supp. 631 (W.D.Ky. 1974) (three-judge court), aff'd in part, rev'd in part, 541 F.2d 523 (6th. Cir. 1976). The reason was that the direct appeals statute, 28 U.S.C. $\S 1253$, only refers to the lower court granting or denying an injunction. Nonetheless, we say generally, because the Supreme Court was not clear on the point. See, e.g., Roe v. Wade, 410 U.S. 113, 122-23 (1973) (permitting direct appeal from three-judge district court which had only issued a declaratory judgment while "dismiss[ing] the application for injunctive relief," in part due to the "specific denial of injunctive relief"). See generally SHAPIRO ET AL., supra note 111, at 2-33 to 2-35 (discussing application of $\S 1253$ in the 1960s and 1970s). Our data does not count the appeals to the courts of appeals as a direct appeal to the Supreme Court.

148. There was little difference on the rate of appeal depending on whether injunctive relief was granted, or not (i.e., whether plaintiff or defendant was appealing). Plaintiffs and defendants appealed in 48 and 47 percent, respectively. Data on file with Solimine. 
the decisions in our database were not unanimous: $12 \%$ had a concurring opinion, while $19 \%$ had a dissent. ${ }^{149}$ While modest, these percentages are still much higher than the historic pattern for the Courts of Appeals, the overwhelming majority of which have been unanimous. ${ }^{150}$ Historically, too, the presence of dissent on a three-judge panel in the court of appeals made it more likely that the losing litigant would file a petition for en banc review, or a petition for a writ of certiorari, and that such petitions would be granted if filed. ${ }^{151}$ Such a dissent could be conceptualized as a whistle-blowing signal in the judicial hierarchy that the case is not routine and could be appropriate for, and make it more likely that, a resource-constrained higher court would review it. ${ }^{152}$ Our data supported the hypothesis that a dissent would more likely lead to a direct appeal. ${ }^{153}$ Of equal and perhaps greater importance, the regime of mandatory appeals required the Supreme Court to, ostensibly, reach the merits of the appeal, so that the attorneys knew that an appeal had some chance to succeed, whether or not there was a dissent. Compare this to a typical long-shot petition for certiorari, of which the Supreme Court has historically granted only a very small percentage. ${ }^{154}$

149. There were 111 decisions with a concurring opinion and 175 with a dissent. Data on file with Solimine. Also, only $4 \%$ (34) had two circuit judges on the panel, rather than just one. Id. In 211 of the cases ( $23 \%$ of the total), there was an unsigned, per curiam opinion. $I d$. For very similar data from a similar study, see Mak \& Sidman, supra note 107, at 125, reporting a study of three-judge district-court decisions in VRA cases, from 1965 to 2016 and showing that $71.7 \%$ were unanimous, with $11.1 \%$ having concurring opinions and $17.2 \%$ having dissenting opinions.

150. For the period we study, see Sheldon Goldman, Voting Behavior on the United States Court of Appeals Revisited, 69 Am. Pol. ScI. Rev. 491, 493 (1975), showing that the dissent rate among all of the circuits from 1965 through 1971 averaged $5.9 \%$.

151. Tracey E. George \& Michael E. Solimine, Supreme Court Monitoring of the United States Courts of Appeals En Banc, 9 Sup. Ct. Econ. Rev. 171, 179-80, 196 (2001).

152. For discussion, see generally Deborah Beim, Alexander V. Hirsch \& Jonathan P. Kastellec, Whistleblowing and Compliance in the Judicial Hierarchy, 58 Am. J. Pol. Sci. 904 (2014); and Frank B. Cross \& Emerson H. Tiller, Judicial Partisanship and Obedience to Legal Doctrine: Whistleblowing on the Federal Court of Appeals, 107 YaLE L.J. 2155 (1998).

153. Of the decisions without a dissent, $45 \%$ were followed by a direct appeal, while for the decisions with a dissent, $70 \%$ were followed by a direct appeal. Data on file with Solimine.

154. Cf. Timothy M. Hagle \& Harold J. Spaeth, The Presence of Lower-Court Amici as an Aspect of Supreme Court Agenda Setting, 30 Just. Sys. J. 1,8 (2009) (finding that a sample of lower-court cases denied review by the Burger Court, including three-judge district court cases summarily affirmed or dismissed, indicated that litigants "view[ed] the chances for Supreme Court review more sanguinely than if the case had also been reviewed by a court of appeals"). See also EPSTEIN ET AL., supra note 80, 
Table 8 presents data on the dispositions of the appeals by the Supreme Court. The most notable aspect of the table is that in only $23 \%$ of the appeals did the Court issue an explanatory opinion while affirming or reversing, while in almost $44 \%$ the Court summarily affirmed. The balance of the appeals, almost 33\%, were disposed of on other grounds. This confirms the long-standing assumption that the Court only resolved less than one-third of these appeals by a full opinion (typically prefaced by oral argument and briefing). This is much higher than the historically tiny rate at which the Court granted writs of certiorari, but it still demonstrates that the Court was policing, in a certiorari-like manner, the relatively large number of direct appeals. ${ }^{155}$ Also notable is that, of the appeals resolved by opinion, the affirmances $(11 \%)$ were not much less than the reversals $(12 \%)$. This too is different from the cases governed by certiorari: there, the Court has routinely reversed the majority of those cases. ${ }^{156}$ Finally, the differences between the circuits found in Table 9 can be largely explained by the smaller number of appeals from some circuits. Most of the disposition rates by circuit were similar to the mean, including the relatively large number of appeals from the Fifth Circuit.

at $72-74$ (providing data on the decline of the granting of certiorari petitions between 1954 and 1976, ranging from $16 \%$ to $10 \%$ ).

155. The large percentages of summary affirmances might also reflect, in part, the Court's effort to engage in Bickelian "passive virtues" by avoiding difficult or controversial issues during the civil rights era. See Alexander M. Bickel, The Least Dangerous Branch: The Supreme Court at THE BAR of Politics 126, 134 (1962) (discussing summary affirmances as an appropriate way for the Supreme Court to avoid especially controversial issues under some circumstances). See generally Erin F. Delaney, Analyzing Avoidance: Judicial Strategy in Comparative Perspective, 66 DukE L.J. 1, 17-18 (2016). More recently, Chief Justice Roberts has expressed concerns in oral arguments (though not in subsequent opinions) that the Court is under an obligation to "decide [direct appeals] on the merits," as opposed to the certiorari regime. See Douglas \& Solimine, supra note 64, at 433 (quoting Transcript of Oral Argument at 38, Shapiro v. McManus, 577 U.S. 39 (2015) (No. 14-990) (Chief Justice Roberts's remarks)). Contrast this putative obligation with the high rates of summary affirmances of three-judge district courts in the era we study, or in earlier times, see, e.g., Felix Frankfurter \& James M. Landis, The Business of the Supreme Court at October Term, 1929, 44 HARV. L. REv. 1, 8, 11 (1930), which discusses the frequent use of summary dispositions during the 1927 and 1928 Terms. Perhaps summary dispositions can be masked by the Court when it is issuing full opinions in many other cases at the same time, while that is more difficult when the Court is, like now, rendering far fewer decisions.

156. EPSTEIN ET AL., supra note 80, at 244-55 (showing that reversal rate from 1954 through 1976 Terms ranged from $53 \%$ to $76 \%$ ). 
Case Western Reserve Law Review $\cdot$ Volume $72 \cdot$ Issue $4 \cdot 2022$

The Strange Career of the Three-Judge District Court

\section{TABLE 1}

THREE-JUDGE DISTRICT COURT HEARINGS, 1952-1980*

\begin{tabular}{|c|c|c|c|c|c|}
\hline YEAR & $\begin{array}{c}\text { CIVIL } \\
\text { RIGHTS** }\end{array}$ & $\begin{array}{l}\text { REAPPORTION- } \\
\text { MENT }\end{array}$ & $\begin{array}{c}\text { ICC } \\
\text { REVIEW }\end{array}$ & OTHER & TOTAL \\
\hline 1952 & & & & & 72 \\
\hline 1953 & & & & & 57 \\
\hline 1954 & & & & & 50 \\
\hline 1955 & & & & & 53 \\
\hline 1956 & & & & & 50 \\
\hline 1957 & & & & & 47 \\
\hline 1958 & & & & & 47 \\
\hline 1959 & & & & & 47 \\
\hline 1960 & & & & & 67 \\
\hline 1961 & & & & & 58 \\
\hline 1962 & & 15 & & & 105 \\
\hline 1963 & 19 & 16 & 67 & 27 & 129 \\
\hline 1964 & 21 & 18 & 50 & 30 & 119 \\
\hline 1965 & 35 & 17 & 60 & 35 & 147 \\
\hline 1966 & 40 & 28 & 72 & 22 & 162 \\
\hline 1967 & 55 & 10 & 64 & 42 & 171 \\
\hline 1968 & 55 & 6 & 51 & 67 & 179 \\
\hline 1969 & 81 & 1 & 64 & 69 & 215 \\
\hline 1970 & 162 & 8 & 42 & 79 & 291 \\
\hline 1971 & 176 & 2 & 41 & 99 & 318 \\
\hline 1972 & 166 & 32 & 52 & 60 & 310 \\
\hline 1973 & 183 & 7 & 52 & 78 & 320 \\
\hline 1974 & 171 & 8 & 51 & 19 & 249 \\
\hline 1975 & 192 & 9 & 47 & 19 & 267 \\
\hline 1976 & 161 & 5 & 25 & 17 & 208 \\
\hline 1977 & 67 & 6 & 2 & 37 & 112 \\
\hline 1978 & 54 & 3 & 0 & 10 & 67 \\
\hline 1979 & 27 & 3 & 0 & 0 & 30 \\
\hline 1980 & 25 & 4 & 1 & 3 & 33 \\
\hline
\end{tabular}

Sources: 1956 Ann. ReP. Dir. Admin. Off. U.S. Cts. 131, 133; 1960 Ann. ReP. Dir. Admin. Off. U.S. Cts. 116-17; 1962 Ann. Rep. Dir. Admin. Off. U.S. Cts. 627-28; 1976 Ann. Rep. Dir. Admin. Off. U.S. Cts. 208-10 tbl.37; 1980 Ann. Rep. Dir. Admin. Off. U.S. Cts. 301 tbl.54.

*Annual Reports provide only totals prior to 1962.

**After 1976, tables break "Civil Rights" category into "Voting Rights" and various other categories. 
Case Western Reserve Law Review · Volume $72 \cdot$ Issue $4 \cdot 2022$ The Strange Career of the Three-Judge District Court

TABLE 2

ORALLY ARGUED THREE-JUDGE COURT CASES ON SUPREME COURT DOCKET, 1953-1980 TERMS

\begin{tabular}{|c|c|c|c|c|c|c|c|c|c|c|}
\hline \hline Term & $\mathbf{1 9 5 3}$ & $\mathbf{1 9 5 4}$ & $\mathbf{1 9 5 5}$ & $\mathbf{1 9 5 6}$ & $\mathbf{1 9 5 7}$ & $\mathbf{1 9 5 8}$ & $\mathbf{1 9 5 9}$ & $\mathbf{1 9 6 0}$ & $\mathbf{1 9 6 1}$ & $\mathbf{1 9 6 2}$ \\
\hline$\#$ & 6 & 5 & 15 & 8 & 12 & 7 & 12 & 9 & 18 & 34 \\
\hline$\%$ & 5.6 & 4.9 & 12.4 & 5.9 & 7.9 & 5.0 & 9.2 & 6.1 & 14.9 & 23 \\
\hline \multicolumn{10}{|c|}{} \\
\hline Term & $\mathbf{1 9 6 3}$ & $\mathbf{1 9 6 4}$ & $\mathbf{1 9 6 5}$ & $\mathbf{1 9 6 6}$ & $\mathbf{1 9 6 7}$ & $\mathbf{1 9 6 8}$ & $\mathbf{1 9 6 9}$ & $\mathbf{1 9 7 0}$ & $\mathbf{1 9 7 1}$ & $\mathbf{1 9 7 2}$ \\
\hline$\#$ & 31 & 22 & 15 & 29 & 26 & 36 & 36 & 41 & 41 & 59 \\
\hline$\%$ & 21.7 & 18.3 & 11.7 & 19.7 & 15.0 & 27.7 & 28.6 & 25.8 & 25.0 & 33.3 \\
\hline \multicolumn{10}{|l|}{} \\
\hline Term & $\mathbf{1 9 7 3}$ & $\mathbf{1 9 7 4}$ & $\mathbf{1 9 7 5}$ & $\mathbf{1 9 7 6}$ & $\mathbf{1 9 7 7}$ & $\mathbf{1 9 7 8}$ & $\mathbf{1 9 7 9}$ & $\mathbf{1 9 8 0}$ & \\
\hline$\#$ & 42 & 56 & 51 & 65 & 22 & 26 & 13 & 4 & & \\
\hline$\%$ & 24.9 & 34.1 & 29.0 & 36.9 & 13.7 & 16.1 & 8.4 & 2.6 & \\
\hline
\end{tabular}

Source: See supra note 80 .

TABLE 3

THREE- JUDGE DISTRICT COURT DECISIONS CHALLENGING STATE LAWS

YEARS

1954-1960

1961-1967

1968-1974

$1975-1978$
TOTAL

$3.7 \%$

33

$18.6 \%$

165

$64.3 \%$

569

$13.3 \%$

118

885 
Case Western Reserve Law Review · Volume $72 \cdot$ Issue $4 \cdot 2022$ The Strange Career of the Three-Judge District Court

\begin{tabular}{|ccc|}
\hline \multicolumn{2}{|c|}{ TABLE 4 } & \\
SUBJECT-MATTER OF DECISIONS & \\
\hline \hline SUBJECT-MATTER & $\underline{\text { NUMBER }}$ & $\underline{\%}$ \\
FOURTEENTH AMENDMENT & 454 & 51 \\
VOTING & 160 & 18 \\
FREE EXPRESSION & 128 & 14 \\
RACE & 58 & 7 \\
ECONOMY & 45 & 5 \\
RELIGION & 18 & 3 \\
OTHER & 22 & $100^{*}$ \\
TOTAL & 917 & \\
\cline { 2 - 2 } & & \\
$*$ ROUNDED & & \\
\hline
\end{tabular}

TABLE 5

THREE-JUDGE DISTRICT COURTS, RULINGS ON REQUESTS FOR INJUNCTIONS, BY CIRCUIT

\begin{tabular}{|ccc|}
\hline \hline CIRCUIT & INJUNCTIONS & TOTAL NUMBER \\
1 & $\frac{\text { GRANTED (\%)* }}{2}$ & 47 \\
2 & $46 \%$ & 133 \\
3 & $48 \%$ & 89 \\
4 & $58 \%$ & 86 \\
5 & $52 \%$ & 232 \\
6 & $40 \%$ & 45 \\
7 & $53 \%$ & 76 \\
8 & $53 \%$ & 51 \\
9 & $54 \%$ & 68 \\
10 & $47 \%$ & 47 \\
DC & $45 \%$ & 11 \\
TOTALS & $51 \%$ & 885 \\
*ROUNDED & & \\
\hline
\end{tabular}


Case Western Reserve Law Review · Volume $72 \cdot$ Issue $4 \cdot 2022$ The Strange Career of the Three-Judge District Court

TABLE 6

THREE- JUDGE DISTRICT COURT DECISIONS, RULINGS ON REQUEST FOR INJUNCTIONS, BY YEARS

\section{YEARS}

1954-1960

1961-1967

1968-1974

1975-1976

TOTALS

\section{GRANTED (\%)*}

$45 \%$

$55 \%$

$51 \%$

$50 \%$

$51 \%$
TOTAL NUMBER

33

165

569

118

885

*ROUNDED

TABLE 7

RATE OF DIRECT APPEALS FROM THREE-JUDGE DISTRICT COURT DECISIONS, BY CIRCUIT

CIRCUIT

2

3

4

5

6

7

8

9

10

DC

TOTALS
RATE OF APPEAL (\%) *

$38 \%$

$63 \%$

$35 \%$

$45 \%$

$47 \%$

$44 \%$

$47 \%$

$43 \%$

$57 \%$

$40 \%$

$55 \%$

$48 \%$
TOTAL NUMBER

47

133

89

86

232

45

76

51

68

47

11

${ }^{*}$ ROUNDED 
Case Western Reserve Law Review · Volume $72 \cdot$ Issue $4 \cdot 2022$

The Strange Career of the Three-Judge District Court

\begin{tabular}{|c|c|c|}
\hline \multicolumn{3}{|c|}{$\begin{array}{l}\text { DISPOSITION BY SUPREME COURT OF DIRECT APPEALS } \\
\text { FROM THREE-JUDGE DISTRICT COURTS }\end{array}$} \\
\hline DISPOSITION & $\underline{\text { TOTALS }}$ & $\begin{array}{l}\text { PERCENTAGE OF } \\
\text { ALL DISPOSITIONS }\end{array}$ \\
\hline SUMMARY AFFIRMANCE & 187 & $44 \%$ \\
\hline REVERSED WITH OPINION & 47 & $11 \%$ \\
\hline AFFIRMED WITH OPINION & 53 & $12 \%$ \\
\hline NO JURISDICTION & 12 & $3 \%$ \\
\hline SUMMARY REVERSAL & 0 & $0 \%$ \\
\hline OTHER & 126 & $30 \%$ \\
\hline TOTALS & 425 & $100 \%$ \\
\hline OUNDED & & \\
\hline
\end{tabular}

\section{The Jurisprudential Impact of the Three-Judge District COURT}

In this Part, we step back from our empirical study to consider a separate but related issue: given the large number of three-judge district-court decisions at both the trial and Supreme Court levels during the 1954-1976 era, what particular impact, if any, did the court have on the content of doctrine? The focus of our empirical study was primarily bottom-up, starting with trial decisions and tracing the fate of many of them in the Supreme Court. Here, in contrast, our primary focus is on the development of doctrine by the Supreme Court. We first address different ways the question of impact can be approached. We then discuss three case studies of the possible impact on doctrine.

\section{A. Competing Models of Impact}

Addressing the jurisprudential impact of any legal change frequently takes some form of counterfactual reasoning: if and how the Supreme Court (or any court) would have addressed a legal controversy in the absence of the change. ${ }^{157}$ We can't be sure with certainty; we

157. See generally Gregory Mitchell, Case Studies, Counterfactuals, and Causal Explanations, 152 U. PA. L. REV. 1517 (2004). 
can't eliminate the change and run history again. What we can do is judiciously examine what did happen for explanatory variables. ${ }^{158}$

Critics of the three-judge district court have long argued that, among other things, the court had little effect on the development of doctrine by the Supreme Court. For example, David Currie argued in the early 1960s that two important Court decisions, Brown and Baker $v$. Carr, which came up on direct appeal from three-judge courts, "would be heard anyway." 159 (A corollary would be that the cases would likely have been filed before individual federal judges in the absence of the three-judge district court.) That is, it is difficult to believe that the high-profile legal issues presented by the school desegregation and reapportionment cases, post-World War II, would not have been brought by plaintiffs (especially when supported by interest groups like the NAACP), or would have escaped the Court's notice, had the cases been litigated in the usual course, and come up by way of certiorari. Perhaps the timing or other aspects of the cases would have been different, and

158. A relevant example would be accessing the impact of Ex parte Young, 209 U.S. 123 (1908). It is frequently stated by leading authorities that the decision had a significant impact on the litigation of civil-rights and constitutionallaw cases in the 20th century. But for the decision, what we now regard as important issues of constitutional law would likely have been litigated in state court as defenses or shields to state enforcement actions, rather than as proactive swords seeking injunctions in actions filed in federal court. In both instances the cases could have eventually reached the United States Supreme Court, but the timing and perhaps holdings and content of the decisions might have differed from what actually happened. See Solimine, Congress, Ex Parte Young, supra note 23, at 102 (citing to work by Professors Charles Alan Wright and Owen Fiss, and opinions by Justices William Brennan and William Rehnquist, among others, making these points). Another relevant example is accessing the impact of the statutory reforms, including the 1976 restriction of the jurisdiction of the three-judge district court, culminating in the 1988 Act which abolished virtually all direct appeals to the Supreme Court from federal and states courts. Arthur D. Hellman, The Shrunken Docket of the Rehnquist Court, 1996 Sup. CT. Rev. 403, 408-09. Scholars have differed on the impact of these changes on the sharp decline of the Supreme Court's merits decisions from the 1980 s to the present. $C f$. $i d$. at 408-12 (arguing that statutory changes played minor roles in causing the shrunken docket), with Ryan J. Owens \& David A. Simon, Explaining the Supreme Court's Shrinking Docket, 53 WM. \& MARY L. REv. 1219, 1278-79 (2012) (giving more weight to the effect of the statutory changes); Kenneth W. Moffett, Forrest Maltzman, Karen Miranda, \& Charles R. Shipan, Strategic Behavior and Variation in the Supreme Court's Caseload Over Time, 37 Just. SYs. J. 20, 33 (2016) (same); and Michael Heise, Martin T. Wells, \& Dawn M. Chutkow, Does Docket Size Matter? Revisiting Empirical Accounts of the Supreme Court's Incredibly Shrinking Docket, 95 Notre Dame L. Rev. 1567, 1573-74 (2020) (same).

159. Currie, supra note 9 , at 74 (footnote omitted). For similar statements, see, e.g., Fed. Jud. Ctr., Report of the Study Group on the Caseload of THE Supreme Court 4 (1972) [hereinafter Freund Report]; Solimine, Voting Rights Litigation, supra note 36, at 105-06. 
indeed perhaps the Court could have benefitted even in these nowiconic cases from some percolation on the issues by different lower courts, a process muted by direct appeals. But these cases, it can be argued, would have come to the Court nonetheless. ${ }^{160}$ This No or Little Effect model is primarily concerned with whether the issues presented in a three-judge district-court case would have reached the Court anyway, by the usual route, but the model inferentially suggests that the content of the Court's decision would likely have been the same as well.

Other scholars have argued, in contrast, that the institutional arrangements of the federal courts in general, and those of Supreme Court review in particular, can have and has had some effect on the content of doctrine. Recently, Andrew Coan has argued that the "judicial capacity" of the Supreme Court can have important impacts on how the Court develops doctrine. ${ }^{161}$ There are far too many cases for the Court to even begin to meaningfully review. In response, he argues, the Court in recent decades has, for the few cases it does agree to review, frequently emphasized relatively bright-line rules of law and deference doctrines, as compared to more opened-ended standards which would require it to engage in time-consuming, fact intensive, case-by-case adjudication. ${ }^{162}$ Similarly, Tara Leigh Grove has argued that the larger number of cases coming up for review, coupled with the certiorari power granted to the Court in the Judiciary Act of 1925, meant that "the Court increasingly had to establish broad precedents for lower courts to apply in the many cases that it lacked the capacity to review." 163 She continues that this meant that "to provide meaningful leadership in this new judicial system, the Court had to craft doctrines that would cabin the discretion of the lower courts." 164

The Little Effect and Judicial Capacity models are not in direct conflict; the former is primarily concerned about the Court hearing a case at all, while the latter is primarily concerned about how the Court decides cases it agrees to hear. And neither Coan nor Grove expressly address direct review of decisions from three-judge district courts. But

160. Cf. Gonzalez v. Automatic Emps. Credit Union, 419 U.S. 90, 99 \& n.17 (1974) (stating that many three-judge district court decisions that are summarily affirmed "would benefit from the normal appellate review.").

161. Andrew Coan, Rationing the Constitution: How Judicial Capacity Shapes Supreme Court Decision-Making 5 (2019).

162. Id. at 3 .

163. Tara Leigh Grove, Tiers of Scrutiny in a Hierarchical Judiciary, 14 GEO. J.L. \& Pub. PoL'y 475, 483 (2016) (discussing the Judiciary Act of 1925, Pub. L. No. 68-415, 43 Stat. 936).

164. Id. at 484 (footnote omitted). Both Coan and Grove acknowledge prior scholarship which made similar arguments, but both seek to more explicitly link the constraints on the Court's review with the content of doctrine developed by the Court. See CoAn, supra note 161, at 491; see also Grove, supra note 163 , at 477 n.6. 
comparing and contrasting both models can shed light on the structural and doctrinal impact, if any, on the institution of the three-judge district court with direct review (or its absence). The Court itself during much of the Warren Court unapologetically expressed concern about the burdens of deciding such cases on direct review. ${ }^{165}$ True, it dealt with the burden, in part, by freely using summary dispositions, mainly affirmances. But even that was attended with considerable awkwardness, since the Court insisted that such dispositions were technically "on the merits." "166

Even with that safety valve, the Court decided considerable numbers of direct appeals with oral arguments and explanatory opinions, as with cases where certiorari was granted. Critics of the three-judge district court in the 1950s and 1960s argued that direct appeals required the Court to spend disproportionate time on unimportant cases and, inferentially, less time on important ones. ${ }^{167}$ The analyses of Coan and Grove suggest that the Court's development of doctrine in those cases may have been influenced, at least in part, by the burden of responding to the direct appeals. That is, at least by implication, the effects of this burden might have been concentrated in the then-frequent direct appeals to the Court. This Judicial Capacity model, then, conflicts to some degree with the model of direct appeals ultimately having little impact on doctrine.

\section{B. Case Studies of Jurisprudential Impact}

Deciding which model (if either one) might best explain the doctrine developed by the Court in direct appeals, during the time period of our study, is no straightforward task. There are no precise metrics for this qualitative study, and of course we cannot say with certitude these cases would, absent direct review, have been decided by the Court in the era we study. We present three case studies involving a variety of substantive and procedural issues that legal scholars of various specialties have deemed important. ${ }^{168}$ To preview our conclusions, we find that for two of three case studies, we can conclude with some confidence that the direct review mechanism had at least some impact on the Court deciding the cases at all, at the time it did, and on the develop-

165. See supra note 50 and accompanying text.

166. Hellman, supra note 82 , at 25-26, 26 n.99.

167. Freund Report, supra note 159, at 4-5; Currie, supra note 9, at 74-75, 75 \& n.367; Chicago Comment, supra note 40, at 564-65.

168. For further discussion of the qualitative analysis of doctrine and the use of case studies, see COAN, supra note 161, at 211-14. 
ment of doctrine. We do not claim that such a relatively modest assertion can be extended to all of the subject-matter areas in our study. But there was some impact in some areas nonetheless. ${ }^{169}$

\section{Reapportionment}

Table 1 provides data on the number of reapportionment cases in the district courts in the era we study. As we already observed, ${ }^{170}$ the burgeoning number of cases in the early and mid-1960s is attributable to the impact of Baker v. Carr ${ }^{171}$ which held that suits challenging malapportioned federal and state legislative districts were justiciable in federal court. Within two years the Supreme Court decided several cases which upheld such challenges on one-person-one-vote grounds, and required that legislative districts in many states be redrawn. ${ }^{172}$ The Court continued to address that issue in the later 1960s, and in fewer cases in the $1970 \mathrm{~s}$, as the application of the one-person-one-vote standard became more settled. ${ }^{173}$

It is difficult to disentangle the institution of the three-judge district court from the history of reapportionment litigation in the federal courts. For that entire history, up to the present day, those cases continued to be heard before such courts, and on direct appeal by the Supreme Court. The Court was deciding such cases, in legal substance virtually identical to Baker $v$. Carr, as far back as the early 1930s. ${ }^{174}$ In Colegrove v. Green the Court famously held that such suits were nonjusticiable political questions. ${ }^{175}$ During the 1950s, the Court summarily affirmed, on the basis of Colegrove and other cases, several further such

169. A fuller examination of other categories of cases and issues in our database is beyond the scope of this Article. Studies of how the Supreme Court builds subject-matter agendas in different eras emphasize the importance of the Court's discretionary authority to select cases to decide. See Richard L. Pacelle, Jr., The Transformation of the Supreme Court's Agenda: From the New Deal to the Reagan Administration 5-10 (1991); Jack M. Balkin, Why Liberals and Conservatives Flipped on Judicial Restraint: Judicial Review in the Cycles of Constitutional Time, 98 TEx. L. REv. 215,216 \& n.8 (2019). One leading study found little to differentiate cases that came up by certiorari or appeals, because as the author saw it, the Court could make "liberal use of a number of tools designed to deny writs of appeals or treat them in a perfunctory manner." PACELLE, supra, at 6 .

170. See supra note 60 and accompanying text.

171. 369 U.S. 186 (1962).

172. Stephen Ansolabehere \& James M. Snyder JR., The End of Inequality: One Person, One Vote and the Transformation of AMERicAn Politics 178 (2008).

173. Hellman, supra note 82 , at 21.

174. E.g., Wood v. Broom, 287 U.S. 1 (1932), rev'g 1 F. Supp. 134 (S.D. Miss. 1932) (three-judge court).

175. 328 U.S. 549, 556 (1946), aff'g 64 F. Supp. 632 (N.D. Ill.) (per curiam) (three-judge court). 
challenges brought before three-judge district courts. ${ }^{176}$ Baker distinguished Colegrove and the subsequent summary affirmances on the basis that they did not squarely address the Equal Protection claim brought in Baker. ${ }^{177}$

Arguably, the three-judge district-court process substantially affected the Court's approach to this issue in the 1960s. ${ }^{178}$ The relative rapidity of Court decisions on reapportionment after Baker is certainly attributable, in part, to the availability of direct appeals to litigation already pending when, or initiated shortly after, Baker was decided. ${ }^{179}$ Plaintiffs, as in Baker itself, had not prevailed in many of the cases, but they were able to promptly secure Court review by direct appeals. ${ }^{180}$ After the Court handed down several decisions further explicating the one-person-one-vote standard in 1963 and 1964, it proceeded to summarily dispose of numerous direct appeals from different states. ${ }^{181}$

The relatively painless Reapportionment Revolution, in its first decade, was also driven in part by the fact that the one-person-one-vote standard was "relatively easy to administer as a matter of math." 182 That wasn't true with apportionment challenges on other grounds that the Court confronted in later decades, such as those under the Voting

176. As recounted in Baker, 369 U.S. at 202-03.

177. Id. at 209, 230-37.

178. Michael E. Solimine, Congress, the Solicitor General, and the Path of Reapportionment Litigation, 62 CASE W. RsRv. L. Rev. 1109, 1136 \& n.135 (2012) [hereinafter Solimine, Path of Reapportionment Litigation].

179. Ansolabehere \& SNyder, supra note 172, at 170-72. A similar pattern occurred a decade later when Roe v. Wade, 410 U.S. 113 (1973), was decided. See Michael E. Solimine, Institutional Effects on Reciprocal Legitimation in the Federal Courts, 70 Vand. L. Rev. En Banc 105, 115-17 (2017) (discussing effects of Roe coming to the Court on direct appeal, and other cases challenging state abortion laws pending on direct appeal at the same time).

180. Solimine, Path of Reapportionment Litigation, supra note 178, at 1138 \& n.143.

181. Richard C. Cortner, The Apportionment Cases 192 (1970). Whether intended by the Court or not, the rapidity of decisions likely had the effect of diluting opposition to the resulting reapportionment of federal and state legislative districts in many states, since it took place almost all at once in the mid-1960s. Solimine, Path of Reapportionment Litigation, supra note 178 , at 1136 . Indeed, by a variety of measures the decisions requiring reapportionment were quickly accepted by interested publics. Id. at 111617. Thus, it might be said that the very process of direct appeals contributed to public acceptance of the decisions.

182. Rucho v. Common Cause, 139 S. Ct. 2484, 2501 (2019). 
Rights Act ${ }^{183}$ or alleged political gerrymandering. ${ }^{184}$ In the Court's recent Rucho v. Common Cause ${ }^{185}$ decision, it definitively held that the latter type of claims were non-justiciable. The majority per Chief Justice John Roberts argued that political gerrymandering lacked an "objective measure" for courts to apply, unlike the one-person-one-vote standard. ${ }^{186}$ He further argued that the Court would need to deal with complicated issues of how one political party was unfairly (or not) treated in redistricting. ${ }^{187}$ Perhaps Chief Justice Roberts, who has suggested that in these cases the Court has some obligation to decide direct appeals, ${ }^{188}$ had concerns with the possibility of the Court hearing frequent direct appeals of political gerrymandering suits (no matter who won below). This might, unfairly as Roberts would see it, constantly suggest to the public that the Court was simply another politicized institution in a polarized time. ${ }^{189}$

Contrast Roberts's apparent concern in 2019 with direct appeals of reapportionment cases in the 1960s and 1970s. It is difficult to say it was not a polarized time; certainly the Warren Court in general didn't lack for political controversy and opposition. ${ }^{190}$ There, the Court was

183. E.g., Thornburg v. Gingles, 478 U.S. 30 (1986) (developing a multi-factor test to apply the 1982 amendments to Section 2 of the Voting Rights Act). Thornburg is an example of a three-judge district court case, 590 F. Supp. 345 (E.D.N.C. 1984), where both constitutional and VRA claims were litigated and decided. See supra note 129.

184. E.g., Vieth v. Jubilirer, 541 U.S. 267, 282-283 (2004).

185. 139 S. Ct. 2484 (2019).

186. Id. at 2501 .

187. Id. at $2499-502$.

188. See supra note 155.

189. Rucho, $139 \mathrm{~S}$. Ct. at 2507 ("[I]ntervention [into partisan gerrymandering] would be unlimited in scope and duration - it would recur over and over again around the country with each new round of districting, for state as well as federal representatives."). See also Douglas \& Solimine, supra note 64 , at 415 (pointing out that Roberts made this point, with an added reference to direct appeals, during oral argument in Gill v. Whitford, 138 S. Ct. 1916 (2018), a political gerrymandering case that was remanded for further proceedings after the Court held that the plaintiffs lacked standing); $c f$. David Cole, Keeping Up Appearances, N.Y. Rev., Aug. 15, 2019, at 18, 19 ("And while there is much to criticize in Robert's gerrymandering decision, . . . the strongest prudential argument in his favor is the risk that, if courts start reviewing such claims, they would be dragged into the partisan muck."). For further discussion of three-judge district-court decisions and direct appeals in this context, see Carolyn Shapiro, Docket Control, Mandatory Jurisdiction, and the Supreme Court's Failure in Rucho v. Common Cause, 2020 Wis. L. REV. 301, 305-13; Michael E. Solimine, Institutional Loyalty and the Design of Partisan Gerrymandering Adjudication in the Federal Courts, 14 N.Y.U. J.L. \& Liberty 171, 179-93 (2020).

190. Powe, supra note 102, at 494-97 (discussing opposition to Warren Court decisions). 
apparently less concerned about the prospect of frequent direct appeals. But of course, the difference was a relatively easy-to-apply legal standard, coupled with popular support (or at worst indifference) to the Reapportionment Revolution, as compared to the Court's decisions on race and criminal procedure. ${ }^{191}$ In that environment, perhaps the Warren Court, while expressing overall concerns with the convening of three-judge district courts and the resulting burdens of direct appeals (as did the Burger Court starting in 1969), was willing to use or tolerate these institutions for this area of law.

We don't want to press the point too far. As we read them, none of the Court's reapportionment decisions or opinions by individual Justices, starting with Colegrove, explicitly suggest concern with a large number of direct appeals from such litigation (or, for that matter, comment about that litigation being brought before three-judge district courts). Moreover, the apportionment exception to the 1976 legislation seems to undercut the notion that reapportionment cases from the 1960s were relatively noncontroversial. As a general matter they arguably were so, but the Congressional drafters, at least, had concerns about the reaction to such decisions from state legislatures, and the perceived bias of a single district judge associated with one political party. ${ }^{192}$

We cannot know for sure, but at least in the lower courts, reapportionment decisions since Baker $v$. Carr may have been even more controversial and politically charged had they not been litigated before three-judge district courts. While Roberts's implicit concern with a large number of direct appeals in some politically charged reapportion-

191. Solimine, Path of Reapportionment Litigation, supra note 178, at 1114 \& n.28. It is worth adding that the Solicitor General of the United States (SG) filed arguably influential amicus curiae briefs supporting the plaintiffs in many reapportionment cases, including Baker v. Carr, 369 U.S. 186, and its progeny, Solimine, Path of Reapportionment Litigation, supra note 178, at 112030 , but not in the political gerrymandering cases, $i d$. at 1128 n.101. The SG filed no amicus brief in Rucho v. Common Cause, 139 S. Ct. 2484 (2019).

192. See supra notes 60-66 and accompanying text. Michael Mullen, a participant in the legislative process culminating in the 1976 Act, observes that there was concern that, absent retention of the three-judge court, a decision (including findings of fact) "might be skewed if the case was heard by a single judge picked by lottery in a multi-judge US district court [either a very liberal or a very conservative district judge] - so the State's new Congressional map would or might reflect a roll of the dice." Mullen E-mail, supra note 66 (brackets in original). For further discussion of forum- and judge-shopping by litigants in these cases, see Pamela S. Karlan, The Rights to Vote: Some Pessimism About Formalism, 71 TEx. L. REv. 1705, 1726-29 (1993); Lisa Marshall Manheim, Redistricting Litigation and the Delegation of Democratic Design, 93 B.U. L. REv. 563, 588-96 (2013); Solimine, Voting Rights Litigation, supra note 36, at 101-04. 
ment cases is not irrational, he may have underappreciated the potential ameliorative impact of the litigation of those cases before three judges, rather than one, in the first instance. ${ }^{193}$

To make the same point a somewhat different way, perhaps Roberts did not undervalue the ameliorative impact of the three-judge court in this context. Rather, what was a virtue to the Warren Court was a vice to the Roberts Court. The former may have affirmatively used the many direct appeals from such courts to quickly set national precedents, even at the cost of the Court being viewed as partisan. The Roberts Court, in contrast, may have seen it as a negative to be frequently in the news in this regard, even at the expense of uniformity on this issue (indeed, Rucho removed federal courts from the process entirely). ${ }^{194}$

\section{Judicial Abstention}

The Supreme Court has long held that federal courts should exercise discretion to decline to proceed (i.e., abstain) with certain cases that otherwise satisfy all procedural and jurisdictional prerequisites, based on federalism concerns. ${ }^{195}$ Abstention may be appropriate if the federal case would interfere with state-court proceedings, as long as federal issues can be raised in those courts, or if state courts should be given the initial opportunity to resolve potentially dispositive issues of state law. ${ }^{196}$ This deference to state-court proceedings is usually referenced in leading Supreme Court decisions, most notably Younger $v$.

193. One of the problems in studying reapportionment decisions, and their political valence, is that it's not always clear how maps of legislative districts, reviewed by or redrawn at the behest of federal judges, are "liberal" or "conservative," or more precisely help one political party or the other (or neither). Mullen E-mail, supra note 66; Solimine, Path of Reapportionment Litigation, supra note 178, at 1143-44. For studies of partisan decisionmaking by members of three-judge district courts in these cases, attempting to deal with these methodological issues, see Randall D. Lloyd, Separating Partisanship from Party in Judicial Research: Reapportionment in the U.S. District Courts, 89 Am. Pol. ScI. Rev. 413 (1995) (study of decisions between 1964 and 1983); Mark Jonathan McKenzie, The Influence of Partisanship, Ideology, and the Law on Redistricting Decisions in the Federal Courts, 65 PoL. Rsch. Q. 799, 799 (2012) (study of decisions between 1981 and 2007).

194. We thank Lael Weinberger for his thoughtful comments on these points and elsewhere in the Article.

195. Zambrano, supra note 51, at 2119 .

196. R.R. Comm'n of Tex. v. Pullman Co., 312 U.S. 496, 501 (1941); FALlon ET AL., supra note 21 , at $1127-71$. 
Harris $^{197}$ from 1971, though many abstention cases preceded and came after that decision. ${ }^{198}$

Both the three-judge district-court statute and the abstention doctrines can be traced to reactions, by Congress and federal judges, respectively, to the impact of Ex parte Young. That case, permitting federal court interference with state regulatory functions, raised tensions with (among other things) traditional state prerogatives to enforce criminal law. ${ }^{199}$ Abstention doctrines can also be traced to advancing the substantive regulatory agenda of the Progressive and New Deal eras, by reducing the potential for federal-court invalidation of state law. ${ }^{200}$ The Supreme Court's fidelity to abstention has waxed and waned: seemingly downplayed in the aftermath of Ex parte Young, it found greater currency from the 1920s to the 1950s, was again cut back by the Warren Court during the Civil Rights era, and finally resurrected at the end of that era in Younger. ${ }^{201}$

Not unlike reapportionment, the history of abstention is bound up with the history of the three-judge district court. Many of the Court's leading cases were direct appeals from three-judge panels. ${ }^{202}$ Consider

197. Younger v. Harris, 401 U.S. 37 (1971).

198. For an overview of Younger abstention, see FALLON ET AL., supra note 21, at 1127-71. Another important abstention doctrine came from Railroad Commission of Texas v. Pullman Co., which held that a federal court should abstain if the case might be resolved by having state courts resolve uncertain issues of state law. 312 U.S. at 501 (reviewing a direct appeal from a three-judge district court). Justice Felix Frankfurter, the author of Pullman and thus a founder of abstention, was, coincidentally or not, a critic of the need for a three-judge district court in general. See Zambrano, supra note 51, at 2119-20; Currie, supra note 9, at 58; Solimine, Congress, Ex Parte Young, supra note 23, at 120 n.100; Lael Weinberger, Frankfurter, Abstention Doctrine, and the Development of Modern Federalism: A History and Three Futures, 87 U. CHI. L. REv. 1737, 1769 \& n.170 (2020).

199. Fred O. Smith, Jr., Abstention in the Time of Ferguson, 131 HaRv. L. REV. 2283, 2289-91 (2018).

200. Edward A. Purcell, Jr., Reconsidering the Frankfurterian Paradigm: Reflections on Histories of Lower Federal Courts, 24 LAW \& Soc. INQUIRY 679, 692, 704 n.73 (1999); Ann Woolhandler, Between the Acts: Federal Court Abstention in the 1940 s and ' 50 s, 59 N.Y.L. ScH. L. REv. 211, 212-13 (2014).

201. Smith, supra note 199, at 2289-96 (tracing the evolution of Younger-type abstention).

202. See, e.g., three decisions cited and quoted in Younger, 401 U.S. at 45-46 (first citing Fenner v. Boykin, 271 U.S. 240 (1926), aff'g 3 F.2d 674 (N.D. Ga. 1925) (three-judge court); then citing Spielman Motor Sales Co. v. Dodge, 295 U.S. 89 (1935) (affirming three-judge district court from S.D.N.Y.); and then citing Watson v. Buck, 313 U.S. 387 (1941), aff'g 34 F. Supp. 510 (N.D. Fla. 1940) (three-judge court)). Not all of the prominent Court decisions on abstention were from direct appeals. E.g., Douglas v. City of Jeannette, 319 U.S. 157 (1943), aff'g 130 F.2d 652 (3d 
the most prominent decision from the Warren Court in 1965, Dombrowski v. Pfister. ${ }^{203}$ That case carved out an apparently robust exception to the abstention doctrine, based on allegations of bad-faith prosecution and, relatedly, enforcement of overbroad state laws impinging on free expression. ${ }^{204}$ There, civil-rights organizations sued in federal court in Louisiana, seeking to enjoin laws of that state that limited political activism under the guise of regulation of subversive activity. ${ }^{205}$ They had been, among other things, served with subpoenas and threatened with prosecution. ${ }^{206}$

A three-judge district court was convened. The majority, invoking familiar abstention principles, denied the injunction request and held that the federal defenses could be raised in state-court proceedings. ${ }^{207}$ Showing open skepticism of a robust role for federal courts in regulating state enforcement of criminal law, the majority stated that "[a] threejudge federal court should not be used as a vehicle to enjoin future enforcement of state statutes . . . ."208 The Fifth Circuit Judge assigned to the panel, John Minor Wisdom, dissented at length, emphasizing that Congress had "instituted [the three-judge district court] for just

Cir. 1942). And not all Court decisions in the pre-civil rights era ordered abstention. Douglas Laycock, Federal Interference with State Prosecutions: The Cases Dombrowski Forgot, 46 U. CHI. L. REv. 636, 642-43 (1979). According to Laycock, between Ex parte Young and Douglas, the Supreme Court decided ninety-four cases on the merits where an injunction was sought against enforcement of a state law, and the Court ordered the injunction in over one-third of those cases. $I d$. An appreciable number of those cases were on direct appeal from three-judge district courts. See, e.g., Hines v. Davidowitz, 312 U.S. 52 (1941), aff'g 30 F. Supp. 470 (M.D. Pa. 1939) (three-judge court); Truax v. Raich, 239 U.S. 33 (1915), aff'g 219 F. 273 (D. Ariz. 1915) (three-judge court); Parker v. Brown, 317 U.S. 341 (1943), rev'd 39 F. Supp. 895 (S.D. Cal. 1941) (three-judge court); Vill. of Euclid v. Ambler Realty Co., 272 U.S. 365 (1926), rev'd 297 F. 307 (N.D. Ohio 1924) (three-judge court). Between Douglas and Dombrowski, the Supreme Court "ordered or affirmed at least" fifty-six district court decisions concerning injunctive or declaratory relief against state laws. Laycok, supra, at 649. An appreciable number of those were on direct appeal from three-judge district courts. $I d$. at 649-50 nn.92-100 (citing such cases).

203. 380 U.S. 479 (1965); Owen M. Fiss, Dombrowski, 86 YALE L.J. 1103, 1103 (1977).

204. Smith, supra note 199, at 2296-300.

205. Dombrowski v. Pfister, 227 F. Supp. 556, 558 (E.D. La. 1964) (three-judge court).

206. Id. at $564-565$.

207. Id. at 561 .

208. Id. The majority also dismissively referred to "the flanking movement" of suing before a three-judge district court to litigate federal limits on state criminal-law enforcement, as opposed to doing so in the state courts themselves. $I d$. at 561 n.2. 
such a case." ${ }^{209}$ The abstention doctrine was distinguishable, he argued, because even those cases had held that deference to state courts was not appropriate when there were "exceptional circumstances," and because the doctrine should be given "a narrow reading in civil rights cases." 210

Judge Wisdom's arguments were largely adopted by the Supreme Court. ${ }^{211}$ There the Court, in an opinion by Justice William Brennan, held that the district court should not have abstained, because the abstention doctrine was "inappropriate for cases such as the present one where . . . statutes are justifiably attacked on their face as abridging free expression, or as applied for the purpose of discouraging protected activities." ${ }^{12}$ Dombrowski soon came to be understood as establishing that the abstention doctrine had little if any effect in cases involving First Amendment rights or arguably bad-faith prosecutions. ${ }^{213}$

That understanding is reflected in the circumstances that led to Younger. In that case, California had indicted Harris for handing out leaflets which allegedly advocated violent political change, purportedly in violation of the state's Criminal Syndicalism Act. ${ }^{214}$ Harris filed suit to enjoin the prosecution in federal court, on the basis that the law violated the First Amendment, and a three-judge district court was convened. ${ }^{215}$ That court acknowledged that abstention principles would ordinarily call for the federal court to defer in lieu of the defense being

209. Id. at 572 (Wisdom, J., dissenting).

210. Id. at 583. As observed by Fred Smith, "[l] ower federal court judges in the American South had an outsized role in shaping . . exceptions" to abstention. Smith, supra note 199, at 2296. These included Fifth Circuit Judges Wisdom of Louisiana, Richard Rives of Alabama, and Elbert Tuttle of Georgia. Id. All three judges served on various high-profile three-judge district courts during the 1950s and 60s, and in the instance of Judge Tuttle, played an apparently strategic role in picking the additional members of such courts during the civil-rights era. Jonathan L. Entin, The Sign of "The Four": Judicial Assignment and the Rule of Law, 68 Miss. L.J. 369, 369 (1998); Solimine, Voting Rights Litigation, supra note 36, at 110-12.

211. Smith, supra note 199, at 2299.

212. Dombrowski, 380 U.S. at 489-90. Justices Black and Stewart did not participate, and Harlan and Clark dissented. Id. at 498.

213. Powe, supra note 102, at 282-83; Glennon, supra note 132, at 925-27. Glennon argues that the "legal profession greeted Dombrowski as a revolutionary departure [from prior abstention cases]. Legal commentators and civil rights lawyers understood Dombrowski as a strategic tool that helped to short-circuit state harassment of civil rights activists. Most lower court decisions following Dombrowski involved civil rights demonstrators." Id. at 926 \& n.404. See also Laycock, supra note 202, at 640-41 (discussing generally how Dombrowski was understood).

214. Harris v. Younger, 281 F. Supp. 507, 508-509 (C.D. Cal. 1968) (threejudge court).

215. Id. 
raised in state court. ${ }^{216}$ But the court, not irrationally, read Dombrowski as carving out an exception "when the criminal statute inherently has a limiting effect upon free expression and when, as here, it is susceptible to unduly broad application." ${ }^{17}$ That law had been famously upheld by the Supreme Court in 1927 in Whitney v. California, ${ }^{218}$ but the court did not find that determinative. Rather, the court found that four decades of intervening decisions by the Supreme Court had expanded First Amendment protection for Harris' advocacy, such that it was "no longer bound by Whitney," and that the law was unconstitutionally broad on its face, thus entitling Harris to injunctive relief. ${ }^{219}$

In what has become the best-known abstention decision, the Supreme Court, in an 8-1 opinion by Justice Hugo Black, disagreed.

216. Id. at 510. The court observed that Harris had unsuccessfully sought writs of prohibition from the California Court of Appeal and Supreme Court to prevent the pending prosecution, showing that he had not "ignored the state courts in seeking to assert their constitutional claims, although [he] presumably would have had a right to do so and come directly here." Id.

217. Id. The court read the later decision of Zwickler v. Koota, 389 U.S. 241 (1967) (Brennan, J.), as endorsing a broad reading of Dombrowski. Younger, 281 F. Supp. at 510-11. That reading was understandable, since Zwickler reversed a three-judge district court which, in a case involving the First Amendment rights of political campaigners, had narrowly construed the "special circumstances" language of Dombrowski. Zwickler v. Koota, 261 F. Supp. 985, 992-93 (S.D.N.Y. 1966) (per curiam). The Supreme Court disagreed and reversed. Zwickler, 389 U.S. at 254-55.

218. 274 U.S. 357 (1927).

219. Younger, 281 F. Supp. at 511, 516-17. Unlike in the lower court opinion in Dombrowski, there was no explicit discussion of the role of the threejudge district court. Id. Cf. Dombrowski v. Pfister, 227 F. Supp. 556, 561 (E.D. La. 1964) (explicit discussion). However, when concluding that it was not bound by Whitney, the court referenced Barnette v. West Virginia State Board of Education, 47 F. Supp. 251 (S.D. W. Va. 1942) (threejudge court), aff'd, 319 U.S. 624 (1943). Younger, 281 F. Supp. at 516 n.2. In a similar fashion to Younger, the three-judge court in Barnette held it was not bound by the Supreme Court's decision only two years earlier in Minersville School District v. Gobitis, 310 U.S. 586 (1940). Barnette v. West Virginia State Bd. of Educ., 47 F. Supp at 253. Indeed, the Supreme Court overruled Gobitis when it affirmed the lower court in Barnette. W. Va. State Bd. of Educ. v. Barnett, 319 U.S. 624, 642 (1943). The inference might be that a three-judge district court stands special among lower courts and has some greater authority to reconsider when it is bound by Supreme Court precedent. See Douglas \& Solimine, supra note 64, at 431 n.118; see also Browder v. Gayle, 142 F. Supp. 707, 718 n.2 (M.D. Ala.) (three-judge court) (Lynne, J., dissenting) (criticizing the lower-court decision in Barnette on this point), aff'd, 352 U.S. 903 (1956); Colegrove v. Green, 64 F. Supp. 632, 634 (N.D. Ill.) (per curiam) (three-judge court) (stating that it disagreed with Wood v. Broom, 287 U.S. 1 (1932), a similar reapportionment case which held (5-4) for the defendant, but as an "inferior court" was it bound by that decision and held for the defendants), aff'd, 328 U.S. 549 (1946). 
The decision "purported to break little new ground." ${ }^{220}$ But it was significant in reaffirming that, as a matter of comity and traditional principles of equity, federal courts should not ordinarily enjoin pending state criminal proceedings when defendants had the opportunity to raise their federal constitutional rights. ${ }^{221}$ The Court also reaffirmed the exceptions to abstention, but overtly construed them narrowly, especially as they had been applied in Dombrowski. The latter decision was essentially limited to its facts. ${ }^{222}$ Thus, the lower court was simply wrong to conclude that there was virtually a free-expression exception to abstention. That doctrinal shift, coupled with the opinion's "soaring federalist rhetoric," helped establish "its special place in the federal courts canon." 223 Scholars have traced that shift to several causes: significant shifts in the nation's political and legal environment; Nixon appointees Warren Burger and Harry Blackmun having succeeded Earl Warren and Abe Fortas on the Court; palpable backlash, jurisprudentially and politically, against Warren Court expansions of federal rights; and that concerns about state judiciaries and criminal justice systems had faded. ${ }^{224}$ What came to be called "Younger abstention" itself expanded in the 1970s in a series of Court decisions applying Younger to varying criminal, and even civil, litigation in state court. ${ }^{225}$

What role, if any, did the three-judge district court play in the development of Younger abstention? The Court itself said relatively little in these decisions about the institution of the three-judge court. ${ }^{226}$

220. Smith, supra note 199, at 2293.

221. Younger v. Harris, 401 U.S. 37, 45 (1971)

222. Id. at $47-49$.

223. Smith, supra note 199, at 2293. Smith particularly refers to Justice Black's invocation of "Our Federalism" as a rationale. Id. at 2295 (quoting Younger, 401 U.S. at 44-45). Surely contributing to the perceived significance of the decision was that the author of the lead opinion was a well-known supporter of the Warren Court's expansion of rights; that only Justice Douglas dissented, while the author of Dombrowski and Zwickler concurred; and that the Court ordered abstention in four companion cases, all direct appeals from three-judge district courts. Weinberger, supra note 198 at 1775; Younger, 401 U.S. at 56 (Brennan, J., concurring); 401 U.S. at 58 (Douglas, J., dissenting); infra note 226.

224. Smith, supra note 199, at 2293-94.

225. See Smith, supra note 199, at 2295. For an overview of these post- Younger decisions, see FALLON ET AL., supra note 21, at 1140-66.

226. The Court did speak to the issue on two occasions. In Steffel $v$. Thompson, the Court held that Younger abstention did not prevent a federal court from issuing a declaratory judgment against a threatened, but not pending, state prosecution. 415 U.S. 452, 461, 475 (1974) (Brennan, J). In reaching that holding, the Court discussed the history of the three-judge district court as a limit on powers bestowed by Ex parte Young. Id. at 465-66. The import of the discussion was not entirely clear. Cf. Bray, supra note 
Nonetheless, it is eye-opening that, as Arthur Hellman reported in his study of the Supreme Court's civil rights docket in the 1970 through 1976 Terms, no less than twenty-four cases involved abstention, "and all but [three] were appeals from three-judge district courts." ${ }^{227}$ Thus, it appears that the direct-appeal mechanism enabled the Court to rapidly revisit and generally expand the reach of Younger abstention in the space of a relatively few years. Perhaps it would have done so anyway by way of grants of certiorari, as Currie might suggest, ${ }^{228}$ but that process would likely have been slower and of a more uncertain outcome for expanding Younger. Another reason for frequently revisiting Younger could have been that expanding the doctrine would eventually lessen the number of direct appeals, as cases are routed in the first instance to state courts.

Hellman presents a more nuanced analysis on the doctrinal effect of such direct appeals. He points out that, in the Court's docket at the time, plaintiffs bringing civil rights actions in federal court, presenting issues that would ordinarily be raised as defenses to state criminal prosecutions, "regularly outnumbered" appeals from such prosecutions. ${ }^{229}$ In the latter cases, "there is little occasion for anyone to invoke doctrines such as standing, ripeness, or Younger abstention." 230 In that

100, at 1098-99 (situating discussion of three-judge district court in Steffel in that decision's broader discussion of judicial federalism). Ironically, the court below had not convened a three-judge district court, even though a state law was challenged and plaintiff had sought injunctive, in addition to declaratory, relief. Steffel, 415 U.S. at 456-457, 457 n.7. The Supreme Court stated that it was unnecessary to convene the court, since the plaintiff had abandoned the request for injunctive relief during the appeal. Id. The other occasion was a year later in MTM, Inc. v. Baxley. 420 U.S. 799 (1975) (per curiam). There, the Court held that a direct appeal from a three-judge district court did not lie when that court denied injunctive relief on Younger abstention grounds, not on a resolution of the merits of the constitutional claim. Id. at 804 . In that instance, plaintiffs could appeal to the circuit court. Id. at 804-05. While the Court's precedents were unclear on the issue, the Court held that a "broad construction" of $\S 1253$ (authorizing direct appeals), permitting a direct appeal in these circumstances, "would be at odds with the historic congressional policy of minimizing the mandatory docket of this Court in the interest of sound judicial administration." Id. at 804. This holding cuts against our notion that direct appeals from the three-judge district court enabled the Court to rapidly expand abstention doctrines. If that were the Court's agenda, MTM should have come out the other way.

227. Hellman, supra note 82 , at 38.

228. See supra, note 159 and accompanying text.

229. Id.

230. Id. at 40 (footnote omitted). A leading example is Roe v. Wade, 410 U.S. 113, 124-27 (1973) (Blackmun, J.) (discussing standing and mootness regarding the plaintiff Roe, and holding that Younger abstention barred consideration of the claims by an intervening physician). Justices Blackmun and apparently 
environment, Hellman suggests, the Court had greater opportunities to address such court-access issues, themselves not totally divorced from the underlying constitutional issues, as compared to a docket instead largely governed by certiorari appeals. ${ }^{231}$

A final possible convergence between abstention doctrines and the three-judge district court is the suggestion that the former made the latter increasingly unnecessary. In the 1960s and 70s, a number of commentators made the argument on the assertion that one of the reasons for the creation of the three-judge court was to demonstrate federalcourt deference to state political institutions. The rise of abstention could be viewed as accomplishing that result without the cumbersome process of assembling a three-judge court with its negative externality of direct appeals. ${ }^{232}$ And the Burger Court's broader agenda of limiting intrusive injunctive relief against states can be seen as driven in part by such injunctions issued by three-judge courts. ${ }^{233}$

There is something to this linkage; the legislative history of the 1976 Act, at the committee report level, approvingly cites Younger as a reason that the three-judge court is no longer necessary. ${ }^{234}$ But we think the linkage can be overstated. As we have argued, the overwhelming reason for the broad support for the 1976 Act was the perceived administrative burden of assembling the courts, and the numerous direct appeals they generated, against a backdrop of an anachronistic concern with cabining Ex parte Young-type injunctions. ${ }^{235}$ The expansion of abstention doctrines, especially by Younger, was indeed an additional factor, but we think only a minor one. Correlation is not causation: while the rise of abstention in the 1970s coincided with the

some of his colleagues initially thought the case might be resolved wholly on abstention grounds. This ground was largely ameliorated by the intervening decision of Mitchum v. Foster, 407 U.S. 225, 243 (1972) (holding that $\S 1983$ actions were an exception to the Anti-Injunction Act, though Younger principles were left intact), rev'g 315 F. Supp. 1387 (N.D. Fla. 1970) (per curiam) (three-judge court). See Clarke D. Forsythe, Abuse of Discretion: The Inside Story of Roe V. Wade 19-24, 361 n.5 (2013); David J. Garrow, Liberty and Sexuality: The Right to Privacy and the Making of Roe V. WAde 528-29 (1994); Вов Woodward \& Scott Armstrong, The Brethren: Inside the Supreme Court 193, 196 (1979).

231. Hellman, supra note 82 , at $40 \&$ n.165. Hellman refers to court access issues as "adjective law doctrines." Id. at 4, 6, 40.

232. See, e.g., John E. Kennedy \& Paul D. Schoonover, Federal Declaratory and Injunctive Relief Under the Burger Court, 26 Sw. L.J. 282, 289-90 (1972); Chicago Comment, supra note 40, at 561. Some of this commentary focused on Pullman rather than Younger abstention. E.g., Harvard Note, supra note 80, at 302; Commentary, supra note 130, at 380.

233. Solimine, Congress, Ex Parte Young, supra note 23, at 139-40, 140 n.193.

234. S. REP. NO. 94-204, at 8 (1975).

235. See supra notes 46-69 and accompanying text. 
Supreme Court's (and much of the rest of the attentive legal establishment's) increasing antagonism with the institution of the three-judge district court, we don't think that the phenomena were directly related.

\section{Judicial Capacity and Tiers of Scrutiny}

As we have recounted, Andrew Coan and Tara Leigh Grove have developed a model of Judicial Capacity that, they argue, helps explain the Supreme Court's development of doctrine regarding Due Process and Equal Protection, including the period covered by our study. ${ }^{236}$ Their focus is on the familiar, if now controversial, ${ }^{237}$ tiers of scrutiny developed by courts to evaluate challenges to those laws. Thus, Coan argues that the large number of government laws and regulations that arguably discriminate in some manner, and the prospect of a large number of suits, influenced the Court to adopt a minimal-scrutiny, rational-basis test to evaluate the constitutionality of most such laws (absent the presence of fundamental rights or suspect classifications). ${ }^{238}$

Grove further discusses the apparent influence of the Judiciary Act of 1925, establishing the discretionary regime of certiorari for the Supreme Court, ${ }^{239}$ but neither she nor Coan explicitly address the continued use of pockets of mandatory jurisdiction, especially from three-judge district court decisions. Their model could be further refined through the lens of direct appeals from such decisions. As Coan puts it, the model has greater explanatory force in constitutional "domains . . . in which the potential volume of litigation is unusually high and those in which the Supreme Court feels compelled to grant review in an unusually large fraction of cases." 240

This closely describes the large number of direct appeals to the Court in the 1960s and 70s. If the Court was motivated (at least in part) by the prospect of many appeals, and further motivated by cabining the discretion of lower courts in such cases, it might have found (at least prior to 1976) the potential avalanche of direct appeals from threejudge district courts (for challenges to both federal and state laws) to be unnerving. Consider that for challenges under substantive due process, several canonical decisions were handed down by the Warren Court, reversing three-judge district courts on direct review, and setting

236. See supra Part III.A.

237. Whether and to what extent the tiers are a relatively recent (i.e., postWWII) jurisprudential phenomenon, and whether they are normatively justified, has been the subject of renewed scholarly interest. See CoAn, supra note 161, at 114-15; Joel Alicea \& John D. Ohlendorf, Against the Tiers of Constitutional Scrutiny, NAT'L AFFs., Fall 2019, at 72, 73-74; Grove, supra note 163, at 475-476, 476 n.3, 478 \& n.8.

238. COAN, supra note 161 , at $130-34$.

239. Grove, supra note 163, at 480-83.

240. CoAn, supra note 161 , at 7 . 
out a deferential, easy-to-satisfy rational-basis standard of review. ${ }^{241} \mathrm{~A}$ parallel list of cases is available for challenges under the Equal Protection Clause. ${ }^{242}$

But here, we don't find a tight connection between those cases and the establishment of tiers of judicial scrutiny. During the Warren and Burger Courts, there are significant counterexamples of decisions following rational-basis scrutiny that were not direct appeals from threejudge district courts. ${ }^{243}$ Similarly, there were significant cases establishing or applying stricter scrutiny that were direct appeals from threejudge courts. ${ }^{244}$ Some of the latter cases involved issues (e.g., gender discrimination $)^{245}$ that would be expected to generate a stream of litigation. The direct-appeal gloss on the Judicial Capacity model is further weakened by the fact that some of the decisions establishing rational-basis scrutiny were handed down before the large number of direct appeals in the late 1960s and early- to mid-1970s. And in its decision-making, the Court no doubt was self-conscious of its public efforts to restrict or eliminate the three-judge district court, and perhaps confident those efforts would succeed.

241. See Ferguson v. Skrupa, 372 U.S. 726, 1031-32 (1963) (state economic regulations), rev'g 210 F. Supp. 200, 202-203 (D. Kan. 1961) (three-judge court); Williamson v. Lee Optical of Okla., Inc., 348 U.S. 461, 463-64, 466 (1955) (same), rev'g 120 F. Supp. 128, 135-36 (W.D. Okla. 1954) (threejudge court).

242. E.g., Mass. Bd. of Ret. v. Murgia, 427 U.S. 307, 313-16 (1976) (per curiam) (mandatory retirement for police), rev'g 376 F. Supp. 753, 756 (D. Mass. 1974) (three-judge court); San Antonio Indep. Sch. Dist. v. Rodriguez, 411 U.S. 1, 55, 59 (1973) (use of property tax for public-school finance), rev'g 337 F. Supp. 280, 282-283 (W.D. Tex. 1971) (per curiam) (threejudge court); Dandridge v. Williams, 397 U.S. 471, 478, 485-86 (1970) (state welfare regulations), rev'g 297 F. Supp. 450, 458-59 (D. Md. 1969) (three-judge court); McDonald v. Bd. of Election Comm'rs, 394 U.S. 802, 806-809 (1969) (right to absentee ballots), aff'g 277 F. Supp. 14, 17 (N.D. Ill. 1967) (three-judge court); see also Pers. Adm'r of Mass. v. Feeney, 442 U.S. 256, 272, 275 (1979) (veterans hiring preference), rev'g $451 \mathrm{~F}$. Supp. 143, 149-50 (D. Mass. 1978) (three-judge court).

243. E.g., McGowan v. Maryland, 366 U.S. 420, 424-26 (1961) (appeal from state courts); City of New Orleans v. Dukes, 427 U.S. 297, 299, 303 (1976) (per curiam), rev'g 501 F.2d 706 (5th Cir. 1974).

244. E.g., Harper v. Va. Bd. of Elections, 383 U.S. 663, 664, 670 (1966), rev'g 240 F. Supp. 270, 270-71 (E.D. Va. 1964) (per curiam) (three-judge court); Kramer v. Union Free Schl. Dist. No. 15, 395 U.S. 621, 622, 62628 (1969), rev'g 282 F. Supp. 70, 71, 74 (E.D.N.Y. 1968) (three-judge court). One might also argue that the three-judge district-court regime led to the establishment of the strict-scrutiny standard, since it too empowers lower courts by establishing a relatively bright-line rule for certain types of cases. See Grove, supra note 163, at 489-90.

245. Craig v. Boren, 429 U.S. 190, 192, 197, 199 (1976) (establishing intermediate standard of review for gender discrimination), rev'g 399 F. Supp. 1304, 1307-09 (W.D. Okla. 1975) (three-judge court). 
To be sure, neither Coan nor Grove claim that the Judicial Capacity model is the sole reason for the Court's creation of tiers of scrutiny; only that it is one, largely overlooked factor. ${ }^{246}$ In this we concur. But we further conclude that, to the extent the Judicial Capacity model has explanatory force, the presence or absence of direct appeals from threejudge districts adds only conflicting variables to the model. ${ }^{247}$

\section{Contemporary Impact: National Injunctions and Returning to Mandatory Jurisdiction}

So far in this section, we have mainly focused on the impact of the three-judge district court on doctrinal developments in the 1960s and 1970s. Here, we consider what lessons might be drawn from that history for two contemporary controversies.

One is the issuance by district judges of nationwide injunctions against the enforcement of federal law. Numerous commentators, echoing Senator Overman's long-ago disdain for a "little" federal judge exercising considerable power, ${ }^{248}$ have been openly incredulous that only one judge should be able to issue an order immediately binding the entire country. ${ }^{249}$ Some commentators have proposed that only a three-judge district court should be able to issue such injunctions. ${ }^{250}$

Yet it is hardly clear that a three-judge district court would achieve the result sought by critics of nationwide injunctions. The reform might

246. CoAn, supra note 161, at 40-46 (discussing legalist, attitudinal, and strategic models as alternative explanations for the Court's decisions); Grove, supra note 163 , at 477 .

247. A counterargument could be premised on the notion that the "early 1970s was a period of great ferment in the development of equal protection doctrine" at the Supreme Court. Earl M. Maltz, The Burger Court and the Conflict over the Rational Basis Test: The Untold Story of Massachusetts Bd. of Retirement v. Murgia, 39 J. Sup. Cт. Hist. 264, 264 (2014). The numerous direct appeals from three-judge district courts in this period, especially, though not only, of lower-court decisions which had held that there was a violation of equal protection, see supra notes $243 \& 245$, provided an opportunity for that ferment.

248. See supra note 27 and accompanying text.

249. See, e.g., John Fund, Why Should a Single Federal Judge Be Able to Make Law for the Whole Country?, NAT'L REV. (July 8, 2018, 6:27 PM), https:// www.nationalreview.com/2018/07/federal-district-judges-should-not-makeimmigration-law-for-whole-country [https://perma.cc/3N3Y-YAXS]; Aaron Blake, The Rise of Solo Judges Nixing Nationwide Policies, Wash. Post https://www.washingtonpost.com/politics/2022/04/20/nationwideinjunctions-trump-biden/ [https://perma.cc/4U65-NEHV] (Apr. 20, 2022, 8:56 A.M. EDT) (nationwide injunctions have "spurred a discussion about whether it's good for our system of government for individual judges to wield such power so frequently.").

250. See supra note 71. See also Cushman, supra note 40, at 1047 (arguing that "ironically" Congress curtailed the three-judge district court in 1976 "just as the universal injunction was emerging as a phenomenon"). 
backfire in several ways. The mere fact that three judges, rather than one, would be convened to consider the issuance of such an injunction might lead to more thoughtful reflection, but it could cut different ways. Three judges might be more willing to than just one to take the controversial step of issuing a nationwide injunction in a high-profile case. This could be true even if we assume that there would be a direct appeal to the Supreme Court. Similarly, given a direct-appeal mechanism, the three-judge court might feel that it is free of the constraints of its geographic circuit, ${ }^{251}$ and is under less restraint to take normal geographic limits of a district judge's jurisdiction into account when deciding whether to issue a national injunction. ${ }^{252}$

The other recent matter is calls for the revival of the long-sincecurtailed mandatory jurisdiction for the Supreme Court, not just for three-judge district court decisions. In 2021, President Joseph Biden signed an executive order creating a presidential commission on the Supreme Court, which among other things was directed to reconsider the Court's case selection processes. ${ }^{253}$ Concerns with the considerable discretion the certiorari process gives to the Supreme Court are nothing new. ${ }^{254}$ Those concerns have now been renewed by commentators from a variety of ideological perspectives and reasons. For example, Jack Balkin has argued that the Court should have less control over its docket as a way to depoliticize the appointment process. ${ }^{25}$ The certiorari process, he contends, enables the Court to lessen its docket, but at the cost of increasing the perceived importance of the fewer cases it does decide, and hence increases the polarization of the Court as a

251. See supra note 135.

252. It is perhaps not entirely irrelevant that the Supreme Court decision that allowed for the possibility of a nationwide injunction was on appeal from a three-judge district court. See Samuel L. Bray, Multiple Chancellors: Reforming the National Injunction, 131 HARV. L. REV. 417, 439-40 (2017) (discussing Flast v. Cohen, 392 U.S. 83, 88 (1968), rev'g Flast v. Gardner, 271 F. Supp. 1 (S.D.N.Y. 1967) (three-judge court)).

253. President Biden to Sign Executive Order Creating the Presidential Commission on the Supreme Court of the United States, White House (Apr. 9, 2021), https://www.whitehouse.gov/briefing-room/statements-releases/ 2021/04/09/president-biden-to-sign-executive-order-creating-the-presidentialcommission-on-the-supreme-court-of-the-united-states/ [https://perma.cc/ 9J7Z-5HBV]. The Commission's final report made no explicit recommendations to change the Court's case selection process. See Presidential Commission on the Supreme Court of the United States, Final REPORT (2021), https://www.whitehouse.gov/wp-content/uploads/2021/ 12/SCOTUS-Report-Final-12.8.21-1.pdf [https://perma.cc/JNK7-F5D2].

254. See, e.g., Edward A. Harnett, Questioning Certiorari: Some Reflections Seventy-Five Years After the Judges' Bill, 100 Colum. L. Rev. 1643, 1713-37 (2000) (discussing tension between certiorari process and rule-oflaw concerns).

255. Jack Balkin, The Cycles of Constitutional Time 151-52, 154 (2020). 
whole. ${ }^{256}$ Similarly, other commentators call for limiting certiorari, and presumably increasing mandatory appeals, to limit the Court's selfimportance $^{257}$ or its strategic behavior. ${ }^{258}$

These commentators are usually not clear on how the current certiorari process should be changed. Most do not explicitly argue that all cases previously governed by certiorari should be the subject of mandatory appeals. But short of that, which cases should be the subject of mandatory appeals, or at least something different than certiorari? One reformer has advocated that randomly selected panels of circuit judges decide which cases the Supreme Court should decide. ${ }^{259}$ Another variation might leave certiorari intact for most cases, but return to some version of the pre-1976 era, with mandatory appeals for certain categories of cases. Such appeals could be from the Court of Appeals, as compared to direct appeals from trial courts (whether three-judge or otherwise).

Whatever models might be advocated, the experience of the Supreme Court with direct appeals from three-judge district courts in the last century suggests that the Court is apt to resist mandatory appeals, for largely the same reasons of sound judicial administration (as the Court perceives it). That experience also suggests that the Court's opposition would be nonideological in nature. Even if more mandatory appeals were enacted, the Court might simply revive its old

256. Id. at $154-55$.

257. Melody Wang, How to Fix the Supreme Court: Don't Let the Court Choose Its Cases, N.Y. Times, (Oct. 27, 2020), https://www.nytimes.com/ interactive/2020/10/27/opinion/supreme-court-reform.html [https://perma. cc/F5WY-2YGH].

258. Matthew J. Franck, The Problem of Judicial Supremacy, NAT'L Affs., Spring 2016, at 137, 147-49 (arguing that Court set up its decision in Obergefell $v$. Hodges by previously denying certiorari in prior appeals that also raised the validity of state bans on same-sex marriage); see also Aziz Huq \& Darrell A.H. Miller, How to Safeguard Progressive Legislation Against the Supreme Court: Poison Pills, WAsh. Post, (Oct. 26, 2020, 6:00 AM), https://www.washingtonpost.com/outlook/2020/10/26/supremecourt-conservative-barrett-progressive-poison-pill/ [https://perma.cc/QHV4$26 \mathrm{PP}$ ] (discussing various strategies for progressive legislators to limit the review of a conservative Court, including adding a provision to legislation that, if ruled unconstitutional, would trigger "a fallback provision that would eliminate the justices' discretion over which cases to hear."); Daniel Epps \& Ganesh Sitaraman, The Future of Supreme Court Reform, 134 Harv. L. Rev. F. 398, 406 (2021).

259. Wang, supra note 257. This proposal closely resembles one advocated in the FREUnd RePORT, supra note 159, at 590-95, at a time when the Court was deciding far more cases than now, in part due to more mandatory appeals. Even so, those recommendations "met a predominately critical response" though "variations have subsequently" been advocated by others. FALLON ET AL., supra note 21, at 47 n.188. 
practice of summarily disposing of such appeals. If so, the modern reformers are apt to be disappointed in the efficacy of the reforms.

\section{Conclusion}

Fifty years ago, the American Law Institute study, quoting David Currie, stated that it was "important to hold in mind that 'the threejudge provisions, despite their bland and technical phrasing, are products of battles between competing political forces over four persistent and significant issues: judicial review, national supremacy, sovereign immunity, and the use of the injunction.'" ${ }^{260} \mathrm{We}$, too, kept in mind competing political forces, broadly defined, as we investigated the use of the three-judge district court in the federal system during a particularly tumultuous period of American history. That period began with the Warren Court, traversed much of the modern Civil Rights era, and ended when Congress significantly limited the types of cases litigated before those courts. It included the 1960s and 70s when large numbers of such courts were convened each year at the district level, and much of the Court's docket was filled by direct appeals of those cases. While the three-judge district court had not gone unnoticed in the scholarship on federal courts in general, or that of the 1956-1976 era, before our study that work was limited in various ways.

To provide a more comprehensive study, we created a database of all officially published three-judge district decisions involving constitutional challenges to a constitutional provision or statute of a state. Our primary focus was on the outcome of the decision, as well as its fate in the Supreme Court, if the losing party filed a direct appeal. Our results were not startling. They largely confirmed what anecdotal and limited empirical evidence had suggested for the era we studied: among the findings were that, on the whole, three-judge courts held for plaintiffs in about half of the cases; almost $50 \%$ of the decisions were the subject of a direct appeal to the Supreme Court; the Court in turn decided about $36 \%$ of those on the merits, while summarily disposing of over $40 \%$.

We also placed those large numbers and dispositions, at trial and on appeal, in a broader institutional context, attempting to discern why so many and what types of such cases were brought, tying them to the legal strategies of plaintiffs in the Civil Rights era. Our focus was less on the legal analysis of the decisions or situating them in broader doctrinal trends. In the latter portion of the Article, we did suggest how the institution of the three-judge district court did make a difference on certain substantive issues, as compared to how those issues might have played out if the three-judge court had not existed.

260. ALI Study, supra note 51, at 318 (quoting Currie, supra note 9, at 3). 
What does our study have to say about the current, continued use of the three-judge district court for reapportionment cases and constitutional challenges to a small number of federal statutes? Considering the strong preference for trial courts staffed by individual judges in the United States, in both the federal and state systems, it is perhaps surprising that the three-judge court has not been entirely abolished. The origins of the court, responsive to the once-controversial, now venerable decision of Ex parte Young ${ }^{261}$ are a distant memory. Yet even the ALI study, while calling for major curtailment of the court's jurisdiction fifty years ago, stated that, in cases of "great public moment," the three-judge court can be supportable since "[t]he moral authority of a federal court order is likely to be maximized if the result cannot be laid to the prejudices or political ambitions of a single district judge." 262

Consider too the recent federal court challenges to partisan gerrymandering. Those were initially brought before and decided by threejudge district courts, and arguably would have been the type of case, per the ALI Study, where a three-judge court would have particularly suited concerns about the partisan affiliation of a single federal judge. ${ }^{263}$ As we noted, the Supreme Court in 2019 put that experiment to an end before the laboratory of the federal court system had fully tested it. ${ }^{264}$ But for now, the three-judge court will live on for other reapportionment cases, and certain challenges to federal statutes. The history of the three-judge court will remain to be told.

261. Ex Parte Young, 209 U.S. 123 (1908).

262. ALI Study, supra note 51, at 320.

263. See generally Richard L. Hasen, Polarization and the Judiciary, 22 AnN. Rev. Pol. ScI. 261, 262 (2019).

264. See supra Part III.B.1. The experiment continues on in the state courts of North Carolina, which adopted a three-judge trial court in 2014 to initially hear constitutional challenges to state statutes. See Joshua A. Yost, Comment, "If It Ain't Broke, Don't Fix It": Evaluating North Carolina's Creation of a Three-Judge Court to Hear Constitutional Challenges to State Law, 93 N.C. L. REV. 1893, 1895 (2015). 


\section{Methodological Appendix}

This appendix provides additional detail on the methodology of our empirical study, as initially addressed in Part II(A) of the article.

\section{Database of Three-Judge District Court Decisions}

We studied three-judge district court decisions in the federal courts, handed down between January 1, 1954 and December 31, 1976, regarding constitutional challenges, under the U.S. Constitution, to state constitutional provisions and state laws. We did not study other types of cases adjudicated before such courts in the time period in question, namely constitutional challenges to federal statutes, certain types of antitrust cases, appeals of orders of the Interstate Commerce Commission, and preclearance actions under the Voting Rights Act of 1965.

While the three-judge district court had been subject to some limited empirical study, there was, as far as we knew, no comprehensive pre-existing database of such decisions for the period in question, from any public or private source. Hence, we needed to create our own database. While several online sources of decisions were available, we decided to use Westlaw. Westlaw itself has no specific keyword or link to three-judge district court decisions as such, so we used several searches to identify the decisions in which we were interested. The decisions are limited to officially published decisions in the Federal Supplement (F. Supp.) and Federal Rules Decisions (F.R.D.). ${ }^{265}$ The searches yielded 885 decisions.

Apart from excluding officially unpublished decisions, due to the vagaries of Westlaw and searches thereof, we cannot say for certain that our database includes all relevant decisions from the period in question. But we are confident that we have systematically assembled a very large fraction of the relevant decisions in our database. A list of the decisions and citations is posted at www.law.uc.edu/directory/ faculty/michael-e-solimine/three-judge-district-court-database.

\section{Coding of Decisions}

Eight students at the University of Cincinnati College of Law coded each decision on the following potentially applicable variables. ${ }^{266}$

1. case name

2. citation in the Federal Supplment

3. U.S. Circuit Court of Appeals where district court convened

265. The searches are collected and discussed in E-mail with Attached Documents from Matthew Allen to Michael E. Solimine (Wednesday, March 2, 2016, $6: 56 \mathrm{pm}$ ) (on file with Solimine). We are particularly appreciative of the substantial contributions of Matt, a 2016 graduate of the University of Cincinnati College of Law, to this project.

266. For more details on these variables, see Michael Solimine \& James Walker, Codebook for Three-Judge District Court Study (January 2017) (available from Solimine and posted on his law-school webpage). 
4. U.S. District Court where district court convened

5. year of decision

6. composition of court (2 district judges and one circuit judge, or two circuit judges and one district judge)

7. names of judges

8. author of lead decision, or if none, indication of unsigned, per curiam opinion

9. author of any concurring and/or dissenting opinions

10. characterization of lead plaintiff (i.e., individual, business, interest group, other)

11. characterization of lead defendant (i.e., state attorney general, other)

12. primary subject of the suit (i.e., racial discrimination; economic regulation; free expression; religion; 14th Amendment claims other than race; voting rights; other)

13. whether injunctive or other relief (e.g., a declaratory judgment) was awarded to the plaintiff

14. if no relief was awarded to the plaintiff, basis of decision (i.e., merits of plaintiff's claims; procedural or other non-merits reasons; other)

15. if there was a direct appeal to the U.S. Supreme Court

16. if there was a direct appeal, the disposition of that appeal (i.e., summarily affirmed or reversed; affirmed or reversed with an explanatory opinion; dismissed for lack of jurisdiction; other).

Two more students, under the direction of one of the authors, subsequently checked and, when necessary, corrected the initial coding of each case by the first wave of student coders. 